Article

\title{
Anthropogenic Activity Effects on Canals Morphology, Case Study: Nile Delta, Egypt
}

\author{
Sherien Abd-Elaziz ${ }^{1}$, Martina Zeleňáková ${ }^{2, *} \mathbb{0}$, Peter Mésároš ${ }^{3}$, Pavol Purcz $^{3}$ and \\ Hany F. Abd-Elhamid 4,5 \\ 1 Ministry of Water Resources \& Irrigation, Zagazig 44519, Egypt; sherien.abdelaziz@eng.zu.edu.eg \\ 2 Department of Environmental Engineering, Faculty of Civil Engineering, Technical, University of Košice, \\ 04001 Košice, Slovakia \\ 3 Department of Construction Technology and Management, Faculty of Civil Engineering, Technical \\ University of Košice, 04001 Košice, Slovakia; peter.mesaros@tuke.sk (P.M.); pavol.purcz@tuke.sk (P.P.) \\ 4 Department of Water and Water Structures Engineering, Faculty of Engineering, Zagazig University, \\ Zagazig 44519, Egypt; hany_farhat2003@yahoo.com \\ 5 Civil Engineering Department, College of Engineering, Shaqra University, Dawadmi 11911, Saudi Arabia \\ * Correspondence: martina.zelenakova@tuke.sk
}

Received: 8 October 2020; Accepted: 9 November 2020; Published: 14 November 2020

check for updates

\begin{abstract}
Waterways are usually contaminated with wastes from industrial, domestic or irrigation sectors. Organizations in charge have adopted solutions to eliminate this problem; however, the adopted solutions contribute indirectly to modifying canal morphology during maintenance. These are examples of anthropogenic activity, as well as randomly implemented dredging, which expand the canal cross-sections. Egypt is a country which depends on surface irrigation through a huge network of canals. The majority of canals in Egypt are subject to anthropogenic activity which affects their efficiency. This study aims to assess the impact of conjugated instances of anthropogenic activity and dredging on canal morphology and capacity. Five canals were selected in the current study in the Nile Delta, Egypt. These canals are highly affected by two associated factors: anthropogenic activity by users and dredging by the government. The study also aims to determine the effects of a newly adopted policy for saving surface water through restoration of the canals' originally designed cross-sections. The results showed a clear change in canal morphology, which has increased the volume of water in the affected canals. In some cases, the volume of water has increased by 59\%, which could have negative consequences for Egypt's water resources. Sustainable management of water resources in Egypt requires saving each water droplet, and canal rehabilitation is expected to save about 6.56 million $\mathrm{m}^{3} /$ year by the year 2022 .
\end{abstract}

Keywords: anthropogenic activity; canal cross-section; dredging; morphology; water volume

\section{Introduction}

Rivers, as well as canals, are waterways, and together they represent a form of surface water feeding. The threat of solid contaminations lies in its settling on the bed and sides of the waterway due to its weight, which forms a layer of pollutants on the waterway bed with time. Khatri et al. [1] reported that anthropogenic activity includes factors which could reduce water quality and hence contaminate the environment. They result from activities in the agricultural sector, such as usage of fertilizers, manures and pesticides, seeds from excess irrigation water back into waterways which may grow into plants, animal husbandry activities and inefficient irrigation practices, but also from pollution due to industrial effluents and domestic sewage, and recreational activities on navigation waterways. These undesirable sediment layers reduce the cross-section areas of canals, hindering 
and disturbing the water movement from the beginning to its destination, and affecting the essential functioning of canals.

Some studies involved in evaluating the quality of surface water due to the anthropogenic activities, such as Singh et al. [2], tested the harmony of water quality status of the Upper Ganga Canal (UGC) with the requirements of the agricultural sector, using the Water Quality Index (WQI). This required the collecting and analyzing of 40 samples of water from five locations from July 2015 to February 2016. The WQI showed that the water quality of the canal is suitable for irrigation purposes. Egessa et al. [3] examined the occurrence, abundance, distribution and chemical of microplastics for the northern Lake Victoria. The results showed the presence of microplastics in all selected sites with an arrangement of 2834: 329,167 particles $/ \mathrm{km}^{2}$. These microplastics originated from plastic materials thrown in surface water as a result of the anthropogenic activities. Furthermore, Khalidullin [4] stated that, to leave the planet safe for future generations, we must preserve water's natural functions.

Periodical canal maintenance is therefore essential to save supplies of supplementary water. Dredging is a suitable technique for removing excess sediment from canal beds and sides. Accordingly, canals should undergo sustainable dredging maintenance to ensure that waterways remain clear (without hindrance) and suitable to perform their function. Several studies have discussed ways of maintaining canals, considering the usual method of reversing the effects of anthropogenic activity, such as Soti et al. [5], which reported that the ways of managing aquatic weeds may be physical or mechanical, biological or chemical. El Ella and El Samman [6] explained the acquired Egyptian experience for application in the field, namely, controlling aquatic weed using biological methods (consumption by grass carp). Bray and Cohen [7] considered the elements of routine maintenance treatment to be stream clearing and scouring, as well as determining the intervention level for work contracts, illustrating the desired conditions after maintenance. Canal maintenance includes both the dredging and removal of weeds. It is implemented in the field either manually or mechanically.

The anthropogenic activity damage the morphology of canals, where it produces garbage, waste products and various scrap items, increases the thickness of accumulated undesirable layers settling on canal beds and sides. Due to this canal morphology is negatively affected, so settled material has to be periodically removed through dredging. Shademani et al. [8] used a robotic system to dredge irrigation canals, which was fabricated in a laboratory at Tehran University. They were concerned that accumulated layers not only hinder the movement of water in the canal, but also contain multi-variable concentrations of heavy metals, which are removed by dredging during regular maintenance activities. Maheshvaran et al. [9] checked the maintenance of smooth navigation along the canal for Haldia Dock Complex with a minimum quantity of dredging, by monitoring the siltation zones. Destefani and Resgalla [10] investigated the physical, chemical and ecotoxicological properties of the sediments in the Linguado canal. The results showed that $\mathrm{Hg}$ and $\mathrm{Ni}$ had high levels exceeding the official limits, and their values did not correlate with time or place. The surface sediments themselves were only slightly contaminated, so they were not considered as a source of environmental contamination, and this contrasted with the results of previous studies in the area. Di Pillo et al. [11] applied the FLORENCE model package to quantify the siltation in the Torrebianca reservoir (south-east Italy), where the majority of both sediment and water comes from the Celone River. The simulation showed that upstream zone and the valley area were the main sources of sediment, and also referred to a range of studies reporting that canal morphology is not fixed due to siltation. Zhang et al. [12] explored the effects of changes in canal morphology on flow in the Shiwuli River, presenting three hydrological connectivity simulations. They ranged from high to medium to low, and demonstrated that there is a strong relation between flows and river morphology.

Yang et al. [13] showed how anthropogenic activity changed the morphology of Lingding Bay from the 1970s until 2011. Although there was siltation in the majority of areas accompanied by decreasing water volume, there was also erosion due to dredging with a resulting overall increase in water volume. Kamal and Sadek [14] looked at navigation on the River Nile and concluded that no relevant or significant records of water levels were taken before implementation of the dredging process. 
On the other hand, after dredging, the situation changed entirely, and the water level experienced a drop of nearly $21 \mathrm{~cm}$ by the year 2003. This decrease intensified with time until 2009 and impacted the efficiency of water pumping stations and navigation on the waterway. The authors therefore recommended applying an integrated dredging strategy along the Nile to avert the side-effects of the procedure.

The sequent effect of anthropogenic activity and dredging process changes the original canals morphology; for example, Dépret et al. [15] studied $13 \mathrm{~km}$ long reservoir on the river Rhône in southern France, considering the rate at which the bed load was transferred downstream, and how to protect the bed morphology. The potential for morphological adjustments increased from the beginning of dam construction to the start of reservoir operation. After the dam construction, therefore, the bed was dredged. The numerical simulations indicated that only small particles could be transferred downstream of the dam. Some studies considered the economic benefits of dredging.

Dredging could have an economic weight, as long as, the implementation restores the original canals morphology, Junakova and Junak [16] focused on the concept of sustainable reuse of sediments produced from the canal dredging process, and how far this raw material could be exploited in the construction industry, such as fabricating lightweight aggregates, bricks and concrete. De Vincenzo et al. [17] adopted an original approach to the reuse of reservoir sediments (Guardialfiera Reservoir, southern Italy) for coastal nourishment, to protect the coast from erosion by using material dredged from reservoirs. They performed both quantitative and qualitative analyses of reservoir sediments, undertaking to find a match between reservoir sediment and beach sand.

The planned dredging is a must as Sobeih et al. [18] reported that organized dredging requires accurate preceding studies before being applied to prevent any issue of cross-section expansion. Mossa et al. [19] stated that legacy systems of dredging influenced the morphology of Appalachicola River canal in Georgia, FL, USA. Kuriqi et al. [20] concluded that the Meyer-Peter and Müller formula could be used for different hydraulic conditions, where the results agreed with the results of two linked different experiments at different flow regimes. Abdelhaleem et al. [21] indicated that the modified Meyer-Peter and Müller (MPM) equation predicted well the rates of bed load transport under the Nile River conditions through field measurements and experimental work. They approved that the modified MPM formula is the most accurate formula for the Nile River conditions. However, Fathy et al. [22] mentioned that the non-uniform formula of MPM is not valid for the case of Nile River, Egypt and need to be improved, as in the selected area of study, where the Nile Delta soil recently characterized by the smallest amount of silt due to the construction of High Aswan Dam (HAD) in upper Egypt. The Delta is located at the end of the Nile River; hence, its share from silting is very poor. Coulthard and Van [23] used the numerical model CAESAR landscape evolution to estimate connectivity in the River Swale basin through four simulations and two simulation added as reference simulations, which resulted in the deforestation in one half of the basin can affect the geomorphology of the other half badly. Thus, the connectivity is, locally, extremely high. Furthermore, Pasculli and Audisio [24] concerned the past two decades to study the morphology of River Pellice, NW Italy, considering silting and scouring depending on instrumental and computational tools. The CAESAR model was used in the simulation; hence, the results compared with statistical approaches.

Waterways in Egypt, particularly canals, have an identical problem as a consequence of anthropogenic activity and the dredging process. The Egyptian canals are exposed to several pollutants: solid pollutants, as well as liquid pollutants due to the anthropogenic activity. Figure 1 presents a selection of photos illustrating major aspects of the Egyptian canals' problems due to obstruction.

Some studies discussed the role of environmental flows in ecosystem conservation away from the side effects of mechanical dredging, such as Ramachandra et al. [25], who used four Spatial-temporal patterns for neighboring riverscapes, central Western Ghats, India, connecting temporal remote sensing data for the period from 1973 to 2018 . The result recorded that there was a $41 \%$ decrease in the green cover, so the perfection of the catchment and the sustainability of stream are essential for integrated watershed management to maintain the anthropogenic and environmental water supply. Kuriqi 
et al. [26] integrated an Eco hydraulic model, hydropower and a hydrologic to evaluate the effect of nine scenarios of hydrologically-based environmental flow on flow regime alteration, hydropower production and fish habitat conditions, considering a run-of-river hydropower plant, Tagus basin river highlighting the water-energy-ecosystem nexus, where inconvenient environmental flows setting has a severe effect on the income from hydropower and the riverine ecosystem. Results showed that merged and dynamic environmental flow scenarios allowed credible hydropower production and affected less than $50 \%$ of habitat loss and flow regime alteration.

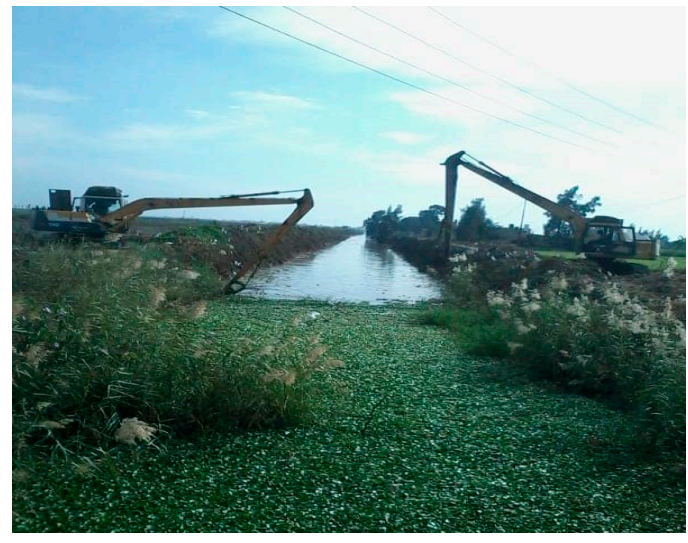

(a)

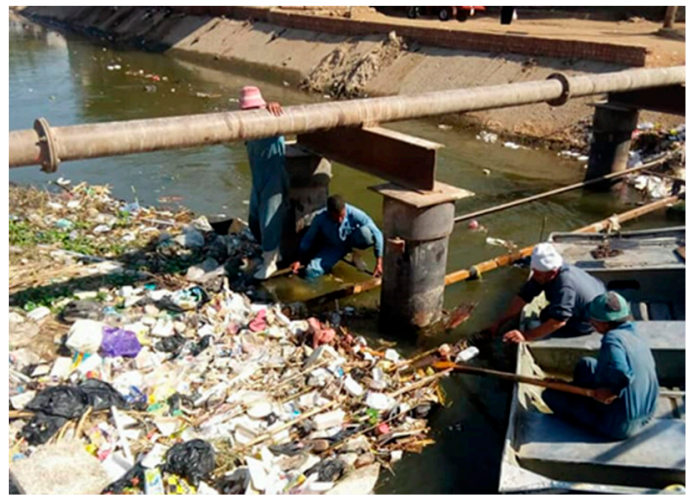

(c)

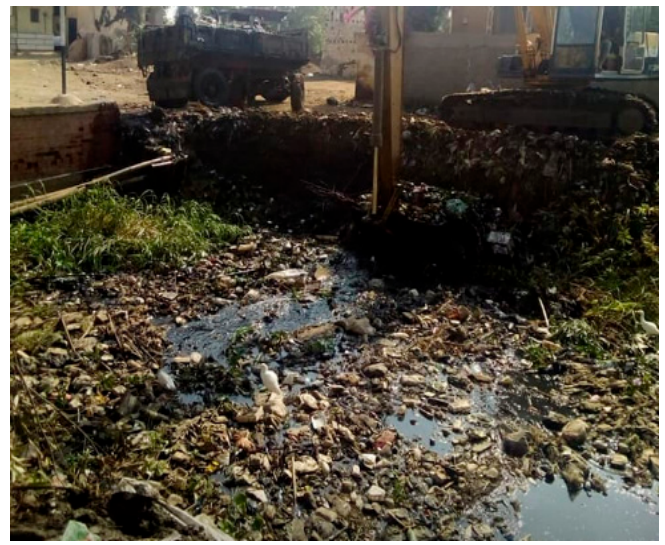

(b)

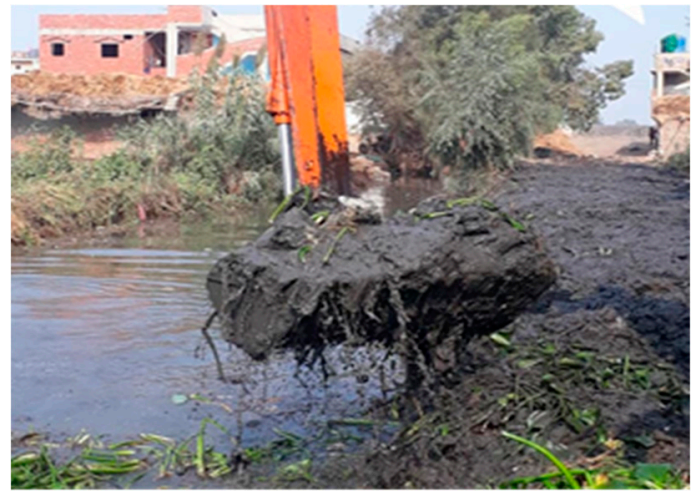

(d)

Figure 1. Photos of various obstructions in irrigation canals. (a) Weed blockage in canal; (b) Accumulation of solid pollutants; (c) Waste blockage at water structure; (d) Dredging of silt and decayed pollutants.

El Kafrawy and Ahmed [27] adopted an environmental management plan through three overlapped scenarios: monitoring, modeling and protecting. They applied Geographic Information Systems (GIS) and hydrodynamic models in the study that recommended future constrains for Egyptian Mediterranean Region. Dutta et al. [28] designated a significant possibility to updating the methodology for the environmental flow estimation centered on the outcomes of hydrological alterations on Indian river ecosystems, science and management of environmental flows, and the necessity for the powerful legislature in developing the nation's water framework directives. The maintenance by dredging, which is implemented to reverse the effects of that activity, is carried out in a random way, which expands the canal cross-sections. Noticing that the dredged volume in the photo is not mainly silt, where the solid pollutants accumulated then decayed, as seen in the photo of Figure 1d. Silting in Egyptian canals is no longer an obstacle after the construction of High Aswan Dam (HAD). These photos confirm that anthropogenic activity degrades the quality of water, as well as changing the cross-section area in a canal, hence its morphology, through reducing the cross-section with accumulated layers of waste material. 
The Egyptian Ministry for Water Resources and Irrigation (MWRI) makes strong efforts to keep the canals functioning (by supplying water to the canal ends) and to attain the condition of well-kept canals. This objective can be achieved through donation contracts under the supervision of MWRI, and by implementing a survey of violations according to the Egyptian Law on Irrigation and Drainage, Law no. 12 in the year 1984. The number of violations committed by local people affecting the environs of the canals reached 1300 by the year 2019, with 1203 resulting in litigation procedures. The MWRI offer contracts every year to maintain the irrigation network across Egypt. The annual cost of the dredging contract/pilot project in Sharkia Governorate, which is implemented three times a year, is almost four million Egyptian pounds; this may rise for hot cross-sections. Dredging proceeds by two means, manual and mechanical, but unfortunately, this procedure has been implemented randomly for many years. Improper mechanical maintenance changes the cross-section shape, whereby extreme canal dredging makes the cross-section wider, and the extraction of excess layers of sediment from canal beds uncovers more than unwelcome layers of pollutants.

In Egypt, water requirements for all aspects of life react directly and strongly to the specified water levels in canals, and the amount of water distribution is related to available levels in the canals. Specified levels for the intake of drinking water stations, inlets of smaller canals and intakes of irrigation systems located along the canals, all require the delivery of certain quantities of water arriving at these levels. Hence, the amounts of water delivered to the required levels in these sections may not correspond to the actual demands, on account of cross-section expansion. At the same time, Egypt still suffers from lack of water resources, particularly surface water, since the population growth in the last few decades has not only consumed the additional water supply but also placed Egypt in a risky position in the field of water management, where demand constantly exceeds the supply.

Sobeih et al. [16] explained the dredging process of the Egyptian canals demands serious follow up to manage the removal of solid pollutants, which becomes a part of the canal's boundaries to avoid enlargement of the canal cross-sections, which drives to a deceptive water supply. In addition, the expanding of canal cross-sections is conjugated by a decrease in rood width. The conceptual realization of this alteration in the Egyptian canals' morphology and the sequent consequences of demanding more surface water and expanding the canals campus missing the stability of canals slope and width of roads enforced the policy of rehabilitation of irrigation canals (RIC). The RIC policy targeted restoring the designed cross-sections of canals to solve the permanent problem of shortage of surface water in the final reaches of canals by releasing surface water to arrive at canals ends. On the other hand, it retains canals slopes and the width of the roads.

This study aims to determine the adverse effects of improper canal dredging, which removes parts of the canal bed and expands the canal cross-section. The study evaluates the changes in canal morphology by comparing the cross-sections in the year 2012 with the original designs. The estimation is performed through simulation for selected canal cross-sections in the study area. Surfer 9 is a good engine for computing the cut or fill volumes in any project, as well as determining the volume of water in cross-sections subjected to invasive maintenance which deforms their original or designed shape and changes their morphology. Surfer is used for calculating the net volume or difference between volumes in the studied area. Comparison of the two phases of canal cross-section measurements established the changes in the cross-sections, which affected the canal morphology, as well as supplementary of water, where expanded cross-sections required more surface water. The study also estimated the applied policy of rehabilitation of irrigation canals to restore the original cross-section by estimating the amounts of saved water.

\section{The Study Area}

The Egyptian canals network starts along the River Nile and is distributed along the Nile valley and the Nile delta. During their journey from source to destination, they are exposed to remarkable variance in cross-section area as a result of additional layers of contaminant sedimentation. A study area was selected in the Nile Delta near Abu Kabir city, which lies in the north of Sharkia Governorate, 
$22 \mathrm{~km}$ north-east of its capital, Zagazig city, as shown in Figure 2. The coordinates of the center of the pilot area are $30.677^{\circ} \mathrm{N}$ and $30.735^{\circ} \mathrm{E}$, as shown in Figure 2, which modified from the latest application of geoportal by MWRI [29]. Figure 2 also showed the location of the selected area, among other Delta cities and with relative to the capital of the governorate and the capital of Egypt, where it is located to the north-east of Cairo city. The study area chose to describe the problem of unplanned dredging, as well as other pilot areas in the Egyptian Delta. The study area forms part of an arid zone, which is hot, dry and rainless in summer, and mild with light rainfall in winter. The mean daily minimum temperature during winter is $12{ }^{\circ} \mathrm{C}$, rising to $37^{\circ} \mathrm{C}$ in the summer, according to Abd-Elaziz et al. [30].

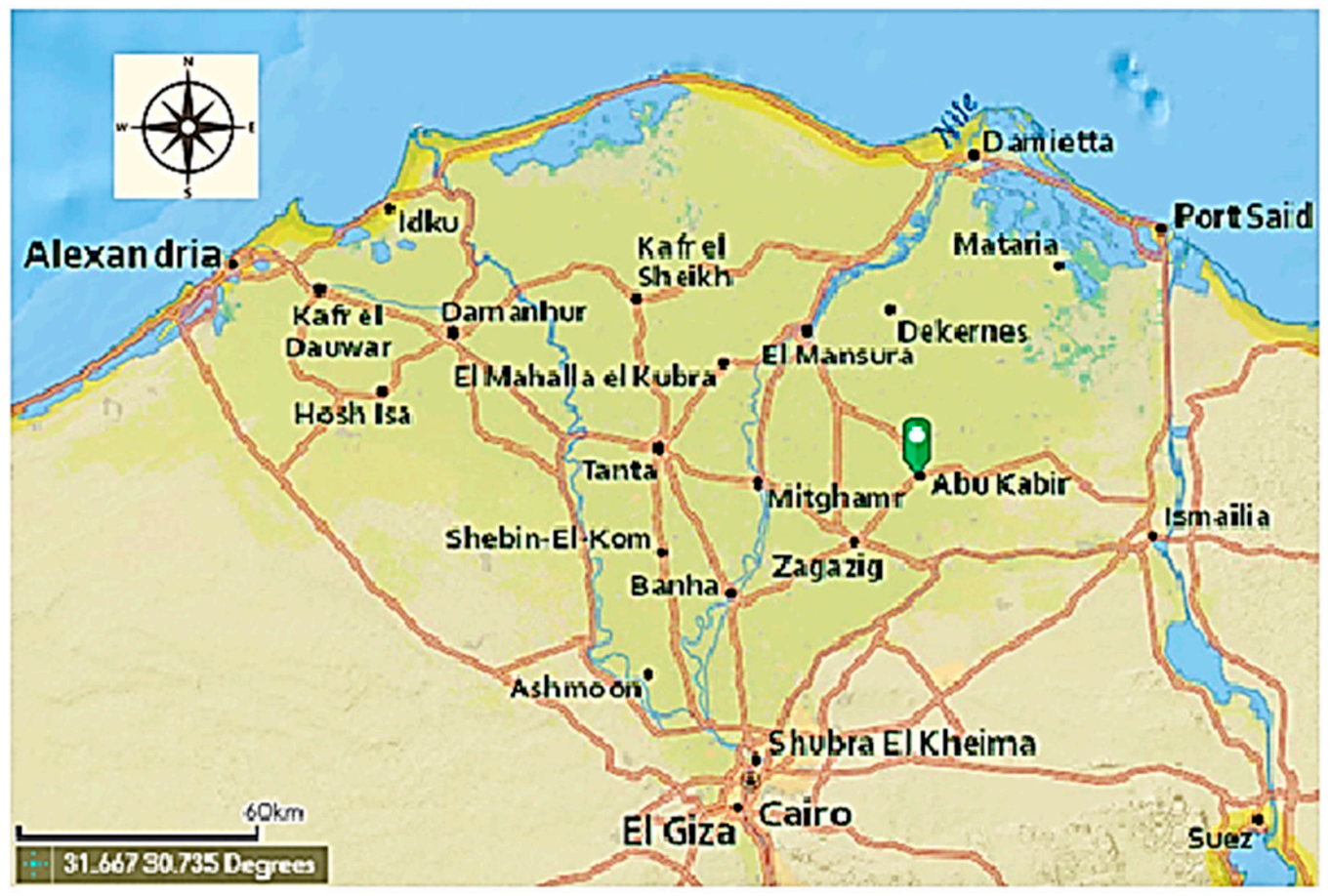

Figure 2. Location map of the study area, MWRI [29].

The served area covers about $348.5 \mathrm{~km}^{2}$, as shown in Figure 2, where 226,000 people lived in 2012. The canal network in the selected area includes 52 waterways distributed as main and branch canals, with a total length of $223.85 \mathrm{~km}$. They are subjected, annually, to severe maintenance in the form of unplanned dredging which deforms the cross-sections, turning them into wider cross-sections requiring more water flow. Irrigation in Egypt has a unique style, working through a network which starts along the river Nile and ends in the Nile Delta. Trandifilo, Mansher, Rageb, Goifel and Mashalaa canals were selected for this study. They represent part of the irrigation network in the study area, with a total length of $17.28 \mathrm{~km}$, i.e., $7.72 \%$ of the total length of canals in the served area. These five canals have the same problem as other 52 canals in the pilot area, which in turn leads to the same problem among the Delta cities. The Egyptian Delta is characterized by soil which is homogeneous in all parts, so all canals are located in clayey soil, as well as the selected canals, so they are suitable for determining the impact of dredging; both the originally-designed cross-sectional areas of the canals (before maintenance) and the actual cross-sectional areas by the year 2017 were available to be calculated. Their comparison enabled the deterioration in canal morphology to be assessed.

Figure 3 was generated by the authors from the geoportal application MWRI [29]. It shows the location of the selected canals in the pilot area, which are subjected to severe dredging, as well as many canals in Egypt; therefore, the selected canals represented the problem of uneven dredging of many canals. The border of the pilot area is in yellow, while the studied canals expressed in green. Most of the studied cross-section was represented on canals plan. 


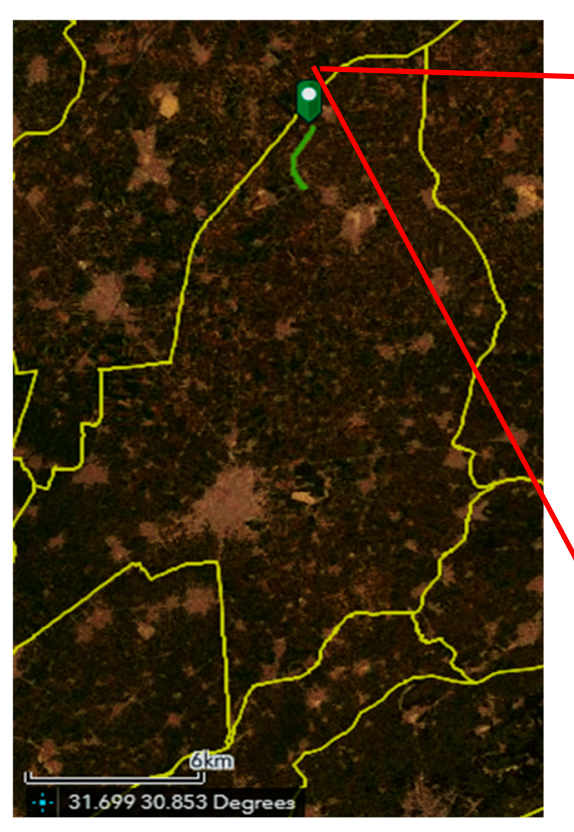

The pilot area
Trandifilo Canal

(a)

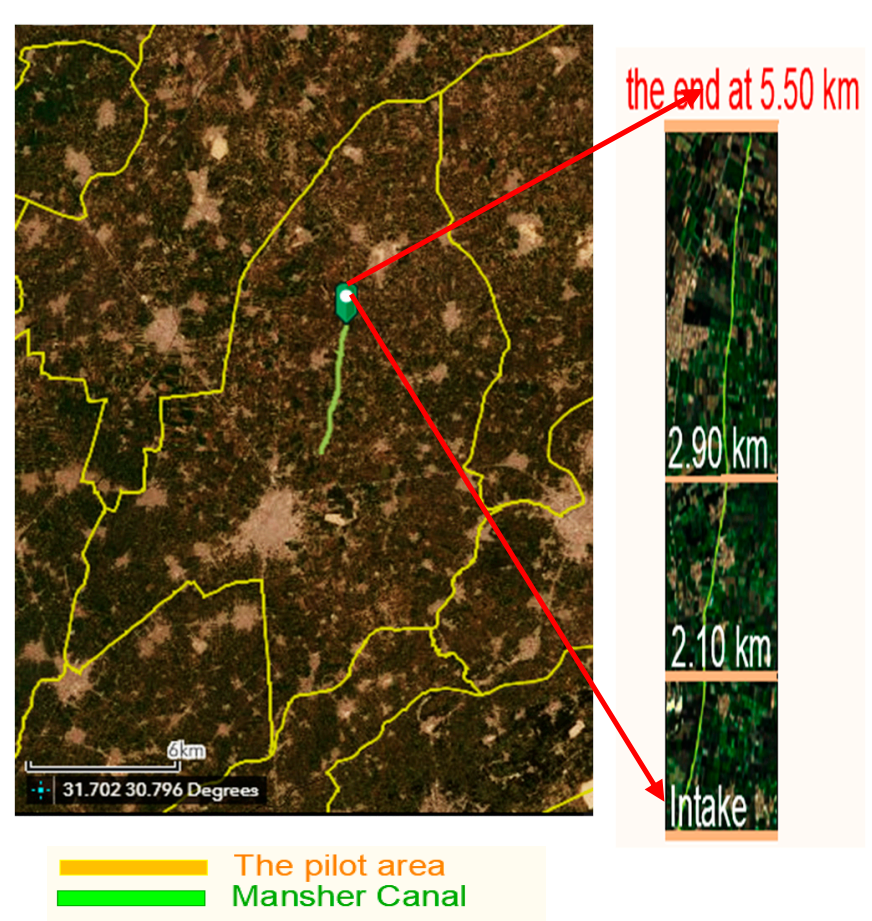

(b)

Figure 3. Cont. 


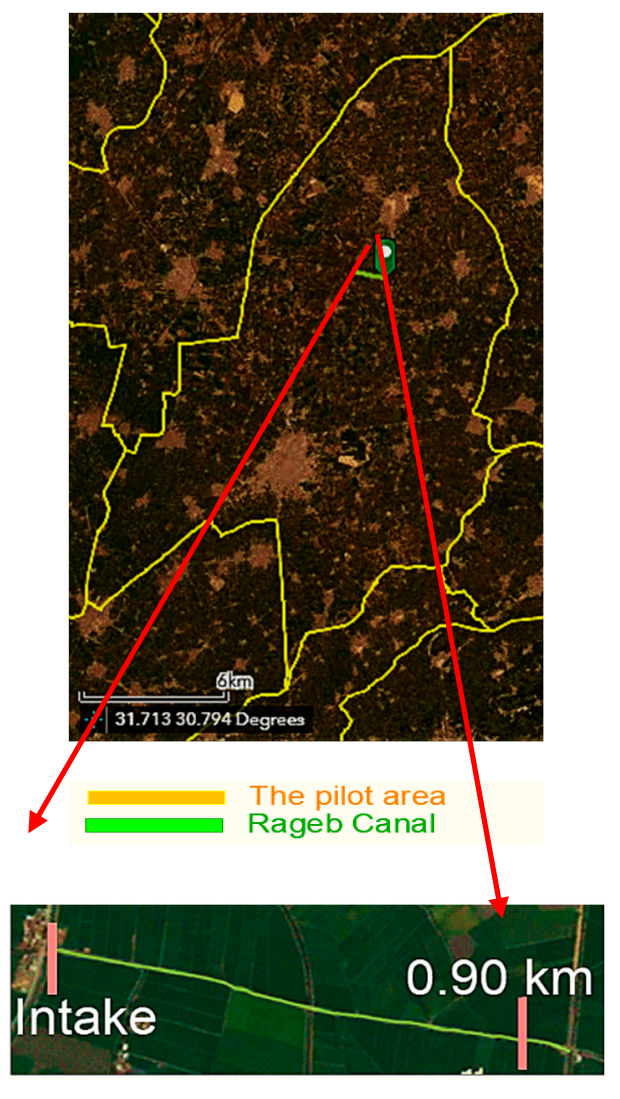

(c)
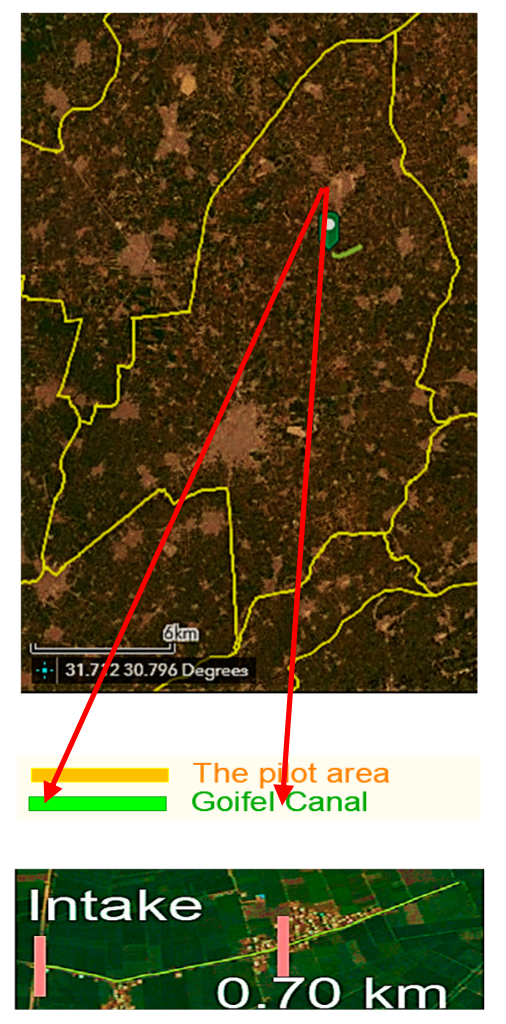

(d)

Figure 3. Cont. 


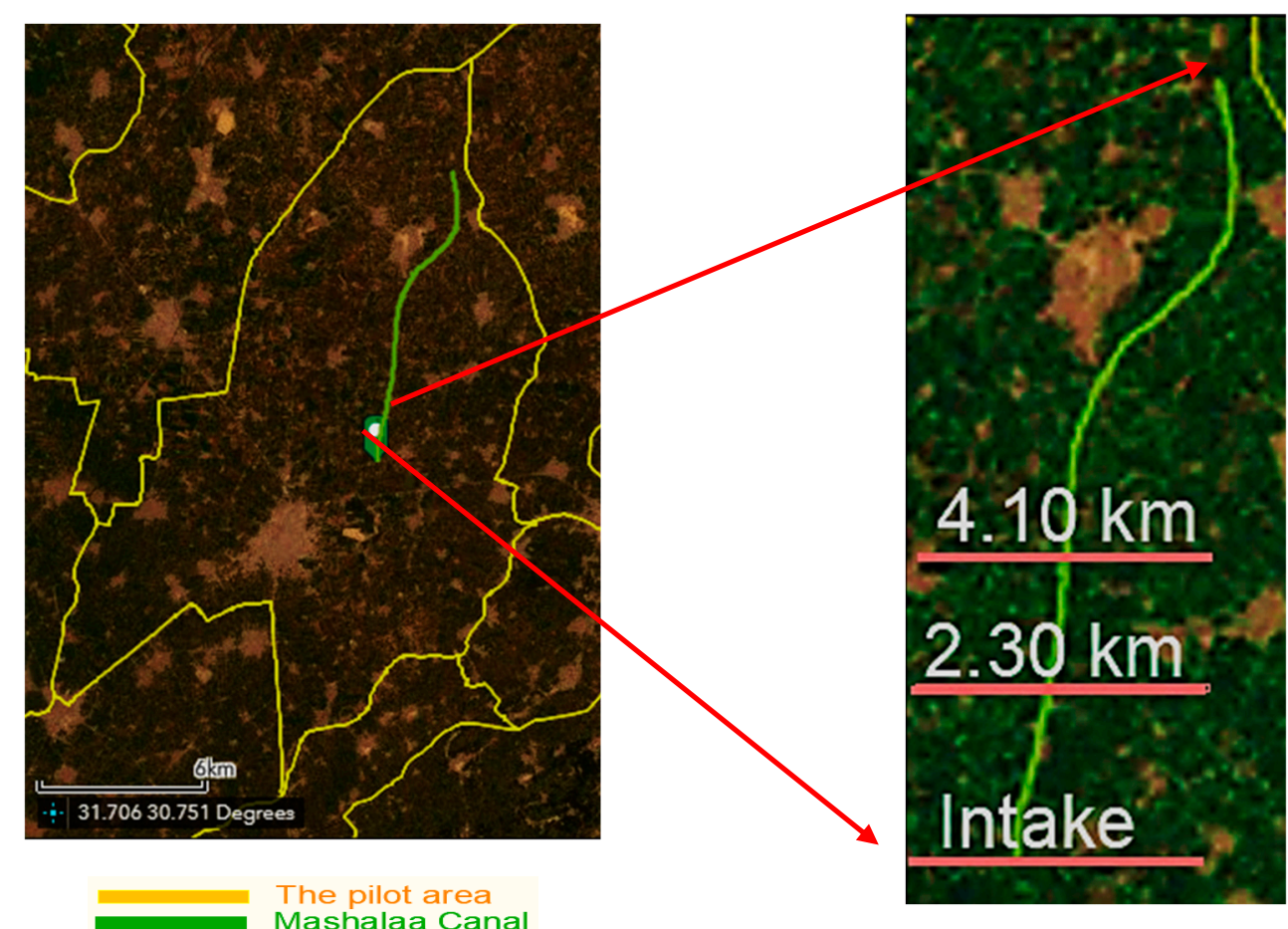

(e)

Figure 3. Location of the selected canals, MWRI [29]. (a) Location of Trandifilo canal; (b) Location of Mansher canal; (c) Location of Rageb canal; (d) Location of Goifel canal; (e) Location of Mashalaa canal. 


\section{Methodology}

The methodology includes acquisition and preparation of required data for the simulation of the study area. Surfer software is utilized for the simulation process, presenting the cross-sections by means of Surfer for two different cases so that the difference shows the change in cross-sections, hence the changing in canals morphology. The simulation aims to determine the variation in canal cross-section and water volume, then compare these with the originally designed cross-section to evaluate the impact of dredging process on canal morphology. A survey of the cross-section patterns for both cases also indicated the change in canal morphology. In the following sections, the program and its terms are discussed. Surfer 9 package software is written for Windows, and converts XYZ Excel sheet data into contour maps and 3D surface maps [30], where $\mathrm{X}, \mathrm{Y}$ and $\mathrm{Z}$ refer to the cross-section dimensions. This conversion helps to find the volume of water in canals for both original and current cross-sections. The net volumes can also be calculated. Figure 4 shows a flowchart for the methodological approach, which includes preparing field data required for simulation. The field data are the dimensions of designed and current cross-sections, discharge and water levels in the canal for each section. It also illustrates the outputs, capacity of designed sections, capacity of current sections and net volume.

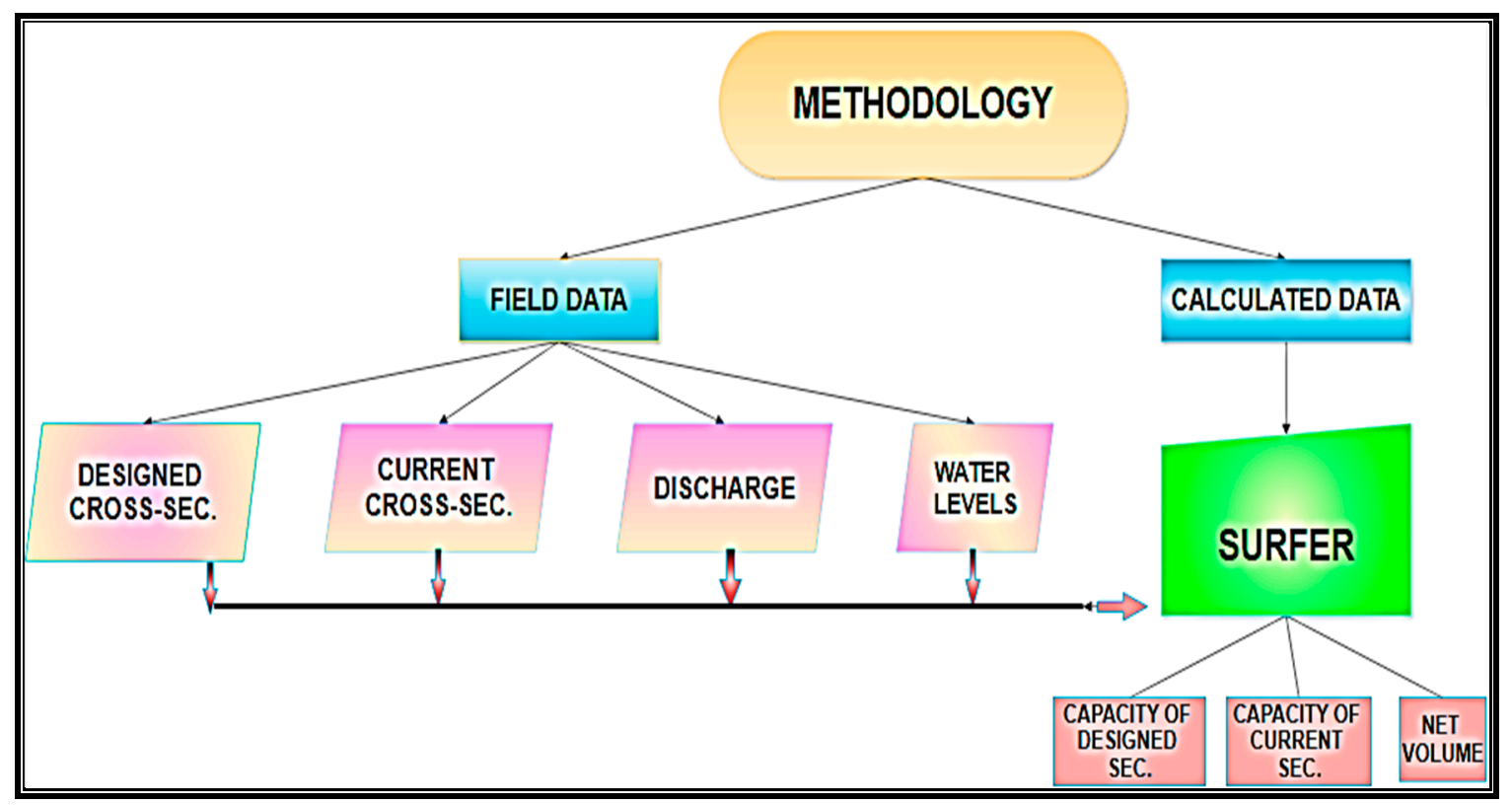

Figure 4. Flowchart of the methodological approach.

\subsection{The Designed Cross-Sections of Canals}

The originally designed cross-sections of canals are mostly trapezoidal shape. The bed width is selected according to the order of the canal, and the side slope (SS) is selected according to the soil type, with a ratio of 1:1. The depth must exceed the maximum water level (WL) by $0.5 \mathrm{~m}$ at least. The land topography dictates the bed slope of each canal (S), with levels on a contour map employed in the synoptic diagram of the canal, where $S$ is the determined of the flow movement in the canal; accordingly, its values should be considered to prevent silting and scouring. Buckley's formula is used to determine the relationship between the canal depth (y), bed width (b) and slope (S). Most of the Egyptian canals have a moderate bed slope of $7: 20 \mathrm{~cm} / \mathrm{km}$, with lower values for approximately flat lands and higher values for steeper slopes. Buckley's, Manning's and Chezy's formulas are considered the governing equations in the design of canals in Egypt. Canals in Egypt adopted the concept of mean velocity which achieves the condition of non-silting and non-scouring, so scouring has negligible effect compared to the impact of the dredging process. 
Due to the anthropogenic activity of people living along open canals, the morphology of the examined canals has changed since they were created. The cross-sectional areas have become narrower, forcing the decision-makers to dredge the canals to retain their function of providing water, but this means that now the canals have been subjected to consecutive severe dredging. Regarding the morphology of the originally-designed canal cross-sections, their simulation using Surfer software was an indispensable step in determining the changes in both water demand and canal morphology before the combined attack on them by the impact of anthropogenic activity and periodical dredging of the selected canals. Five Excel sheets prepared for the selected canals illustrate the data files of the original cross-sections. Table 1 presents the required data for the simulation of the designed canal cross-section. The data signify the bed width, bed level, bed slope and side slope. Bed level, water level and all levels of cross-sections appear in the format of levels as followed in Egypt (0.00), where the brackets around the numbers mean that they are above mean sea level (m.s.l.), where the Mediterranean Sea level represents the zero level in Egypt. Hence, the bed level of the Goifel canal (2.98) means that the bed in this section is above m.s.l by $2.98 \mathrm{~m}$.

One fairway reach represents each of the Goifel and Rageb canals, with lengths of $1.225 \mathrm{~km}$ and 1.1 $\mathrm{km}$, respectively, while two reaches provide the data for the Trandifilo and Mansher canals separately, with lengths of $2.7 \mathrm{~km}$ and $5.5 \mathrm{~km}$, respectively, and four reaches express the data of Mashalaa canal, with a combined length of $10.95 \mathrm{~km}$. The details of the canal cross-sections in Table 1 represent the designed cross-sections and the early stage of operation in these canals. MWRI has recorded these data for all canals in the Egyptian network as unpublished data for the designed cross-sections, as described in Table 1. The raw data in Table 1 are converted into data files, which Surfer calls "blanking files". The blanking file indicates the coordinates of the map in three dimensions, where $\mathrm{X}$ coordinate sets the interval between cross-sections along the studied canals at one meter, $Y$ coordinate indicates the length of the described reach, and $Z$ coordinate values refer to the elevation for each point $(X, Y)$ at the cross-section, which represents the topographic elevation and the water level in the canal. Once the XYZ grid spreadsheet is composed, the contour map and 3D map can be created. The same procedures are then performed for the other four canals to determine the original volume of water in the canal sections before dredging started.

Table 1. Details of originally-designed cross-sections for the five canals MWRI [29].

\begin{tabular}{|c|c|c|c|c|c|c|c|}
\hline $\begin{array}{l}\text { Canal } \\
\text { Name }\end{array}$ & From & To $(\mathbf{k m})$ & $\begin{array}{c}\text { Bed } \\
\text { Width (m) }\end{array}$ & $\begin{array}{l}\text { Bed Level } \\
\text { (m) }\end{array}$ & $\begin{array}{l}\text { Bed Slope } \\
(\mathrm{cm} / \mathrm{km})\end{array}$ & SS & $\begin{array}{c}\text { Total } \\
\text { Length }(\mathbf{k m})\end{array}$ \\
\hline Goifel & intake & 1.225 & 1.00 & $(3.00)$ & 5 & $1 / 1$ & 1.225 \\
\hline \multirow{2}{*}{ Trandifilo } & intake & 1.865 & 1.50 & $(2.00)$ & 8 & $1 / 1$ & \multirow{2}{*}{2.700} \\
\hline & 1.865 & 2.70 (end) & 1.00 & $(1.85)$ & 8 & $1 / 1$ & \\
\hline \multirow{2}{*}{ Mansher } & intake & 3.110 & 2.00 & $(3.60)$ & 11 & $1 / 1$ & \multirow{2}{*}{5.500} \\
\hline & 3.110 & 5.500 (end) & 1.00 & $(3.25)$ & 5 & $1 / 1$ & \\
\hline Rageb & intake & 1.100 (end) & 1.00 & (3.30) & 10 & $1 / 1$ & 1.100 \\
\hline \multirow{4}{*}{ Mashalaa } & intake & 4.85 & 3.50 & $(3.15)$ & 9 & $1 / 1$ & \multirow{4}{*}{10.950} \\
\hline & 4.85 & 6.500 & 2.50 & $(2.65)$ & 10 & $1 / 1$ & \\
\hline & 6.500 & 9.730 & 2.00 & $(2.50)$ & 10 & $1 / 1$ & \\
\hline & 9.730 & 10.950 (end) & 1.50 & $(2.15)$ & horizontal & $1 / 1$ & \\
\hline
\end{tabular}

\subsection{The Current Cross-Sections of Canals}

This step evaluates changes in canal morphology including canal cross-sections and volume of water flows in canals, as compared with the originally designated values. This comparison not only illustrates changes in canal morphology due to dredging intended for removing the traces of anthropogenic activity, but also uses volumes of water flow in the sections measured to reveal the effects of dredging on the canals. The other five Excel sheets prepared for the five canals display data files for the operating canal sections. Table 2 shows data required to simulate the operating sections of 
Goifel, Trandefilo, Mansher, Rageb and Mashalaa canals, including bed width, bed level and water level for the selected cross-sections. Canal sections were assessed twice annually, before and after dredging procedure, to estimate the amounts of removed layers through comparison between the two states, while the comparison between designed and current cross-sections achieved the study objective: to evaluate the changes in canal morphology and compute the volumes of water to the two states. This estimation was conducted based on fieldwork. The data reported in Table 2 were measured by MWRI. MWRI measured the cross-sections of canals which were included in dredging contracts twice. The initial measurement was taken before starting dredging, and final measurement was performed after the completion of maintenance by means of dredging.

Table 2. Details of operative cross-sections for the five canals [29].

\begin{tabular}{|c|c|c|c|c|c|c|c|}
\hline $\begin{array}{l}\text { Canal } \\
\text { Name }\end{array}$ & From & To $(\mathbf{k m})$ & $\begin{array}{c}\text { Length of } \\
\text { Section }(\mathrm{Km})\end{array}$ & $\begin{array}{c}\text { Location of } \\
\text { Cross-Section }(\mathrm{km})\end{array}$ & $\begin{array}{c}\text { Bed } \\
\text { Width (m) }\end{array}$ & $\begin{array}{c}\text { Bed } \\
\text { Level }\end{array}$ & $\begin{array}{l}\text { Water } \\
\text { Level }\end{array}$ \\
\hline \multirow{2}{*}{ Goifel } & intake & 0.500 & 0.500 & 0.300 & 1.00 & $(2.98)$ & $(5.80)$ \\
\hline & 0.500 & 1.225 & 0.575 & 0.700 & 1.00 & $(2.96)$ & $(5.80)$ \\
\hline \multirow{3}{*}{ Trandifilo } & 0.500 & 1.000 & 0.500 & 0.700 & 1.50 & $(1.96)$ & $(4.57)$ \\
\hline & 1.000 & 1.865 & 0.865 & 1.500 & 1.50 & $(1.88)$ & $(4.51)$ \\
\hline & 1.865 & 2.700 (end) & 0.835 & 2.300 & 1.00 & $(1.78)$ & $(4.49)$ \\
\hline \multirow{9}{*}{ Mansher } & intake & 0.600 & 0.600 & 0.300 & 2.00 & $(3.57)$ & $(6.51)$ \\
\hline & 0.600 & 1.200 & 0.600 & 0.900 & 2.00 & $(3.50)$ & $(6.51)$ \\
\hline & 1.200 & 1.800 & 0.600 & 1.500 & 2.00 & $(3.44)$ & $(6.33)$ \\
\hline & 1.800 & 2.500 & 0.700 & 2.100 & 2.00 & (3.39) & $(6.27)$ \\
\hline & 2.500 & 3.110 & 610 & 2.900 & 2.00 & $(3.31)$ & $(6.25)$ \\
\hline & 3.110 & 3.600 & 0.590 & 3.300 & 1.00 & (3.23) & $(6.19)$ \\
\hline & 3.600 & 4.300 & 0.700 & 3.900 & 1.00 & (3.17) & (6.13) \\
\hline & 4.300 & 4.900 & 0.600 & 4.500 & 1.00 & (3.11) & $(6.10)$ \\
\hline & 4.900 & 5.500 (end) & 0.600 & 5.300 & 1.00 & $(3.03)$ & (5.96) \\
\hline \multirow{2}{*}{ Rageb } & intake & 0.600 & 0.600 & 0.300 & 1.00 & $(3.26)$ & $(6.22)$ \\
\hline & 0.600 & 1.100 (end) & 0.500 & 0.900 & 1.00 & $(3.22)$ & (6.17) \\
\hline \multirow{18}{*}{ Mashalaa } & intake & 0.600 & 0.300 & 0.300 & 3.50 & $(3.11)$ & $(6.12)$ \\
\hline & 0.600 & 1.200 & 0.600 & 0.900 & 3.50 & $(3.07)$ & $(6.11)$ \\
\hline & 1.200 & 1.900 & 0.700 & 1.500 & 3.50 & $(3.02)$ & $(6.05)$ \\
\hline & 1.900 & 2.500 & 0.600 & 2.300 & 3.50 & (2.95) & (5.96) \\
\hline & 2.500 & 3.100 & 0.600 & 2.900 & 3.50 & $(2.88)$ & $(5.84)$ \\
\hline & 3.100 & 3.800 & 0.700 & 3.500 & 3.50 & $(2.83)$ & (5.78) \\
\hline & 3.800 & 4.300 & 0.500 & 4.100 & 3.50 & $(2.79)$ & $(5.76)$ \\
\hline & 4.300 & 4.850 & 0.550 & 4.500 & 3.50 & $(2.75)$ & $(5.75)$ \\
\hline & 4.850 & 5.500 & 0.650 & 5.100 & 2.50 & $(2.60)$ & (5.57) \\
\hline & 5.500 & 6.000 & 0.500 & 5.700 & 2.50 & $(2.55)$ & (5.55) \\
\hline & 6.000 & 6.500 & 0.500 & 6.300 & 2.50 & $(2.51)$ & (5.55) \\
\hline & 6.500 & 7.100 & 0.600 & 6.900 & 2.00 & $(2.48)$ & (5.52) \\
\hline & 7.100 & 7.700 & 0.600 & 7.300 & 2.00 & $(2.44)$ & $(5.36)$ \\
\hline & 7.700 & 8.400 & 0.700 & 8.100 & 2.00 & $(2.36)$ & (5.33) \\
\hline & 8.400 & 9.100 & 0.700 & 8.700 & 2.00 & $(2.30)$ & (5.13) \\
\hline & 9.100 & 9.730 & 0.630 & 9.500 & 2.00 & $(2.22)$ & (5.03) \\
\hline & 9.730 & 10.400 & 0.670 & 9.900 & 1.50 & $(2.12)$ & $(5.01)$ \\
\hline & 10.400 & 10.950 (end) & 0.550 & 10.700 & 1.50 & $(2.05)$ & $(5.00)$ \\
\hline
\end{tabular}

These measurements enable MWRI to compute the removed amounts of undesirable sediment from canals. As this style of maintenance affects the morphology of the Egyptian canals, MWRI limited maintenance to hot sections only, so the table presents data from the years 2011/2012. The fieldwork consisted of longitudinal and cross-sectional leveling. The longitudinal leveling started from a nearby point at a fixed level (benchmark) and settled on a graduated marble ruler in any adjacent canal. The longitudinal leveling established a series of levels starting from the benchmark until the desired 
cross-sections were arrived at. The longitudinal leveling generated levels for every $100 \mathrm{~m}$ for accuracy, and when the wanted cross-sections were reached, the bed levels for every point $/ \mathrm{m}$ were estimated and water levels measured at the points of crossing for cross-sections and water surfaces. Cross-sections were taken at the canal intakes and ends, and along the given sections in between. Each measured cross-section expressed a specified distance, so the position of these sections varied from one canal to another. Level, folding staff and tape were the instruments used in the leveling process. Water levels in the canals fluctuated throughout the year according to the canals' needs; in this study, we were interested in the maximum water levels in the canals, because they represent the worst case in each estimation. Table 3 presents the details of the sections.

Table 3. Details of designed and operative cross-sections for the five canals MWRI [29].

\begin{tabular}{|c|c|c|c|c|c|c|c|c|c|c|c|c|c|}
\hline $\begin{array}{l}\text { Canal } \\
\text { Name }\end{array}$ & $\begin{array}{r}\text { Width of Cro } \\
\text { (m) }\end{array}$ & -Section & 0 & 1 & 2 & 3 & 4 & 5 & 6 & 7 & 8 & 9 & 10 \\
\hline \multirow{6}{*}{$\begin{array}{c}\text { Goiefel } \\
\text { canal }\end{array}$} & \multicolumn{2}{|c|}{ Designated levels (m) } & 6 & 5 & 4 & 3 & 3 & 4 & 5 & 6 & - & - & - \\
\hline & \multirow{5}{*}{$\begin{array}{c}\text { Operated } \\
\text { cross-sections } \\
\text { level }(\mathrm{m})\end{array}$} & intake & 5.82 & 4.2 & 3.32 & 2.92 & 2.92 & 3.18 & 4.33 & 5.79 & - & - & - \\
\hline & & $3 \mathrm{~km}$ & 5.82 & 4.2 & 3.32 & 2.92 & 2.92 & 3.18 & 4.33 & 5.79 & - & - & - \\
\hline & & $7 \mathrm{~km}$ & 5.8 & 4.92 & 4.24 & 3.2 & 2.85 & 2.85 & 3.17 & 4.02 & 4.88 & - & - \\
\hline & & $9 \mathrm{~km}$ & 5.8 & 4.92 & 4.24 & 3.2 & 2.85 & 2.85 & 3.17 & 4.02 & 4.88 & - & - \\
\hline & & $12.25 \mathrm{~km}$ & 5.8 & 4.92 & 4.24 & 3.2 & 2.85 & 2.85 & 3.17 & 4.02 & 4.88 & - & - \\
\hline \multirow{8}{*}{$\begin{array}{c}\text { Mashalaa } \\
\text { canal }\end{array}$} & \multicolumn{2}{|c|}{ Designated levels (m) } & 6.07 & 5.1 & 4.1 & 3.1 & 3.1 & 3.1 & 3.1 & 3.8 & 4.7 & 5.7 & 6.6 \\
\hline & \multirow{7}{*}{$\begin{array}{c}\text { Operated } \\
\text { cross-sections } \\
\text { level }(\mathrm{m})\end{array}$} & intake & 6.04 & 4.32 & 3.3 & 3.02 & 2.9 & 2.9 & 3 & 3.22 & 4.35 & 4.92 & 6.12 \\
\hline & & $0.9 \mathrm{~km}$ & 6.1 & 4.5 & 3.4 & 3 & 2.92 & 2.92 & 3 & 3.2 & 4.3 & 5.32 & 6.12 \\
\hline & & $1.5 \mathrm{~km}$ & 6 & 4.38 & 3.5 & 2.9 & 2.82 & 2.82 & 2.84 & 3.1 & 3.5 & 4.71 & 6.1 \\
\hline & & $2.3 \mathrm{~km}$ & 5.92 & 4.33 & 3.3 & 2.9 & 2.81 & 2.81 & 2.83 & 3.22 & 3.85 & 4.82 & 6 \\
\hline & & $2.9 \mathrm{~km}$ & 5.8 & 3.82 & 3.2 & 2.8 & 2.7 & 2.72 & 2.72 & 3.1 & 4 & 4.72 & 5.8 \\
\hline & & $3.5 \mathrm{~km}$ & 5.74 & 4.01 & 3.12 & 2.72 & 2.6 & 2.6 & 2.72 & 3 & 3.8 & 4.77 & 5.82 \\
\hline & & $4.1 \mathrm{~km}$ & 5.72 & 4 & 3.1 & 2.7 & 2.61 & 2.61 & 2.7 & 3.02 & 3.77 & 4.65 & 5.8 \\
\hline \multirow{3}{*}{$\begin{array}{c}\text { Rageb } \\
\text { canal }\end{array}$} & \multicolumn{2}{|c|}{ Designated levels (m) } & 6.07 & 5.1 & 4.1 & 3.1 & 3.1 & 3.1 & 3.1 & 3.8 & - & - & - \\
\hline & \multirow{2}{*}{$\begin{array}{c}\text { Operated } \\
\text { cross-sections } \\
\text { level }(\mathrm{m})\end{array}$} & intake & 6.04 & 4.32 & 3.3 & 3.02 & 2.9 & 2.9 & 3 & 3.22 & - & - & - \\
\hline & & $0.9 \mathrm{~km}$ & 6.1 & 4.5 & 3.4 & 3 & 2.92 & 2.92 & 3 & 3.2 & - & - & - \\
\hline \multirow{9}{*}{$\begin{array}{c}\text { Mansher } \\
\text { canal }\end{array}$} & \multicolumn{2}{|c|}{ Designated levels (m) } & 6.1 & 5.1 & 4.2 & 3.5 & 3.5 & 3.5 & 4.4 & 5.35 & 6.5 & - & - \\
\hline & \multirow{8}{*}{$\begin{array}{c}\text { Operated } \\
\text { cross-sections } \\
\text { level }(\mathrm{m})\end{array}$} & intake & 6.1 & 5.02 & 4.02 & 3.42 & 3.38 & 3.42 & 4.12 & 4.93 & 6.51 & - & - \\
\hline & & $0.9 \mathrm{~km}$ & 6.1 & 4.03 & 3.03 & 2.39 & 2.37 & 2.39 & 3.05 & 4.17 & 6.52 & - & - \\
\hline & & $1.5 \mathrm{~km}$ & 5.32 & 3.53 & 2.66 & 2.31 & 2.21 & 2.31 & 2.91 & 3.82 & 5.33 & - & - \\
\hline & & $2.1 \mathrm{~km}$ & 6.1 & 3.82 & 2.8 & 2.32 & 2.22 & 2.32 & 3 & 3.97 & 6.5 & - & - \\
\hline & & $2.9 \mathrm{~km}$ & 6.1 & 4.52 & 3.6 & 3.22 & 3.12 & 3.22 & 3.9 & 4.88 & 6.28 & - & - \\
\hline & & $3.9 \mathrm{~km}$ & 6.1 & 4.5 & 3.4 & 3.1 & 3.1 & 3.5 & 4.52 & 6.15 & 6.1 & - & - \\
\hline & & $4.5 \mathrm{~km}$ & 6 & 5.22 & 4.3 & 3.3 & 3 & 3 & 3.52 & 4.39 & 5.3 & 6.2 & - \\
\hline & & $5.5 \mathrm{~km}$ & 5.92 & 4.51 & 3.32 & 2.9 & 2.9 & 3.35 & 4.38 & 6 & - & - & - \\
\hline \multirow{4}{*}{$\begin{array}{c}\text { Trandifilo } \\
\text { cacal }\end{array}$} & \multicolumn{2}{|c|}{ Designated levels (m) } & 5 & 4 & 3 & 2 & 2 & 2.7 & 3.5 & 4.5 & 5.5 & - & - \\
\hline & & Intake & 4.62 & 3.4 & 2.35 & 1.9 & 1.83 & 2.11 & 2.9 & 3.88 & 4.52 & - & - \\
\hline & & $1.5 \mathrm{~km}$ & 4.53 & 3.32 & 2.39 & 1.82 & 1.72 & 2.01 & 2.7 & 3.69 & 4.48 & - & - \\
\hline & & $2.3 \mathrm{~km}$ & 4.48 & 3.42 & 2.6 & 1.82 & 1.7 & 1.7 & 1.88 & 2.5 & 3.39 & - & - \\
\hline
\end{tabular}

Surfer software calculated water volumes in the canals successfully. It used three methods to compute volumes: The Trapezoidal Rule, Simpson's Rule and Simpson's 3/8 Rule. The variation in volume calculations between the three methods was very small, and their values nearly equal to the measured volumes. Surfer not only calculates the volume of water for both dredged and originally-designed sections, but also calculates the difference between the two volumes to estimate the additional amount of water required in each canal, as a side-effect of dredging Bresnahan and Dickenson [31]. Mathematically, the volume under function $\mathrm{f}(\mathrm{x}, \mathrm{y})$ is defined by a double integral, Equation (1), where the first integration is over $x$ to compute the area, and the second integration is over $y$ to determine the final volume: 


$$
\text { Volume }=\iint f(x, y) d x \cdot d y
$$

Estimation of actual discharge $\left(\mathrm{Q}_{\mathrm{act}}\right)$ through the canals was obtained from fieldwork by MWRI. The actual discharge is important for assessing the excess volumes of water per day or per year. The values of actual discharge were: $2.12 \mathrm{~m}^{3} / \mathrm{s}, 2.64 \mathrm{~m}^{3} / \mathrm{s}, 2.88 \mathrm{~m}^{3} / \mathrm{s}, 2.09 \mathrm{~m}^{3} / \mathrm{s}$ and $1.97 \mathrm{~m}^{3} / \mathrm{s}$ for the Goifel, Mansher, Mashalaa, Rageb and Trandifilo canals, respectively.

\section{Results}

Changes in morphology of the studied canals and volumes of water in the studied sections were determined. The results cover the changes in required water for each canal, by calculating the net volume or difference between volumes of water in the canal cross-sections before maintenance utilizing dredging considering the designed cross-sections and then after dredging regarding the operated cross-section of canals. The results also reveal noticeable changes in canal cross-sections after decades of dredging, which deform canal shape and distort canal morphology. The simulations for designed and current cross-sections were performed to the selected five canals. Figure 5 shows an example of the results of the simulations performed using Surfer software. It presents a comparison between contour and 3D maps for the original (designed) and current cross-sections of Goifel canal in four maps.

\subsection{Effects of Dredging on Canal Morphology}

Canal morphology is highly affected by sustained anthropogenic activity and subsequent maintenance in the form of dredging. The results of the simulation show severe changes in the cross-sections of canals, as shown in Figure 6 for Goifel canal.

Figure $5 \mathrm{a}, \mathrm{b}$ show the contour maps of the designed and current cross-sections, which indicate remarkable changes in the canal cross-sections. All designed cross-sections look smaller than the operative one; the bed width in Figure $5 \mathrm{a}$ is $7 \mathrm{~m}$, but it appears widened to $8 \mathrm{~m}$ in Figure $5 \mathrm{~b}$. While the horizontal direction refers to the bed width in $\mathrm{m}$, the vertical direction refers to the length of the canal in $\mathrm{km}$. Figure 5c,d show 3D maps of the same cross-sections. The 3D maps show the canal of Goifel in the three directions; these include the bed width $(\mathrm{m})$, the canal length $(\mathrm{km})$, and the level of points/cross-section $(\mathrm{m})$ and comparison between the two figures reveals that the canal cross-sections have widened. Each color in the 3D maps refers to a range of levels, as indicated in Figure 5 . The comparison between the contour maps, as well as between the 3D maps, shows that the current cross-sections of Goifel canal need more surface water to reach the desired level of surface water supply. 


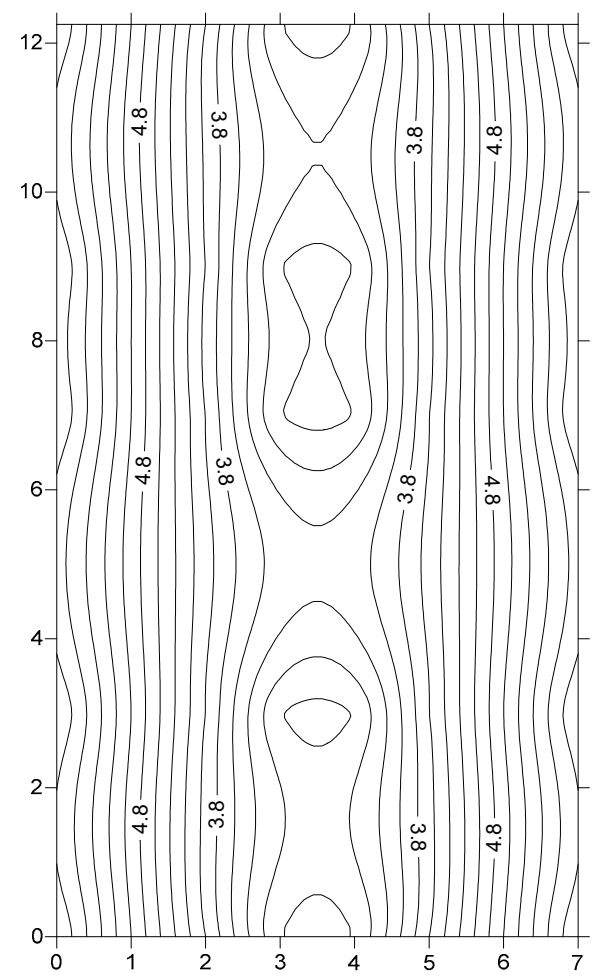

(a) Contour map of designed cross-section

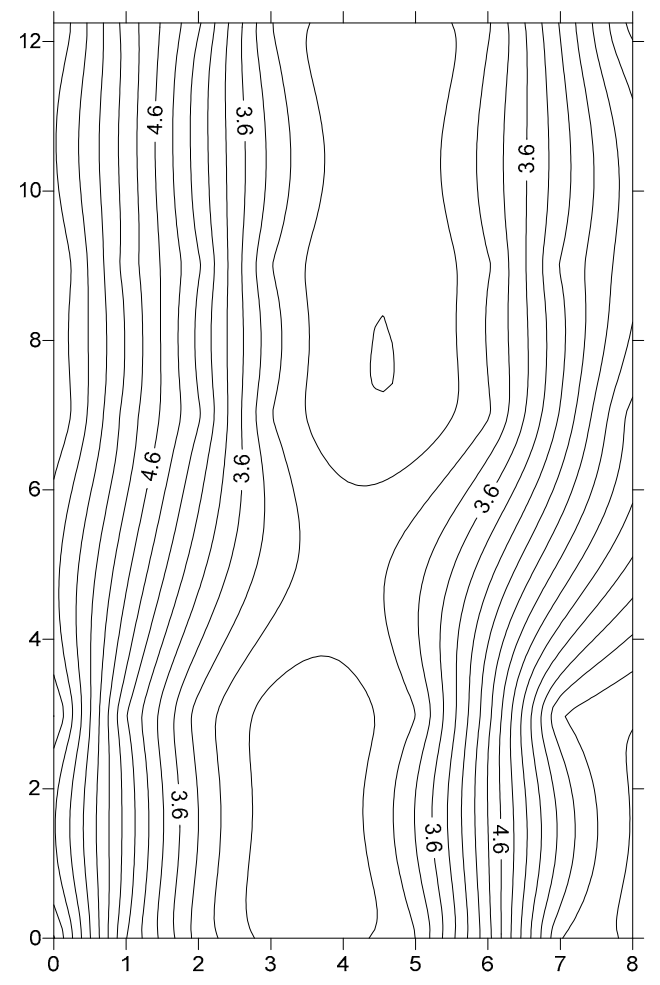

(b) Contour map for the current cross-section

Figure 5. Cont. 


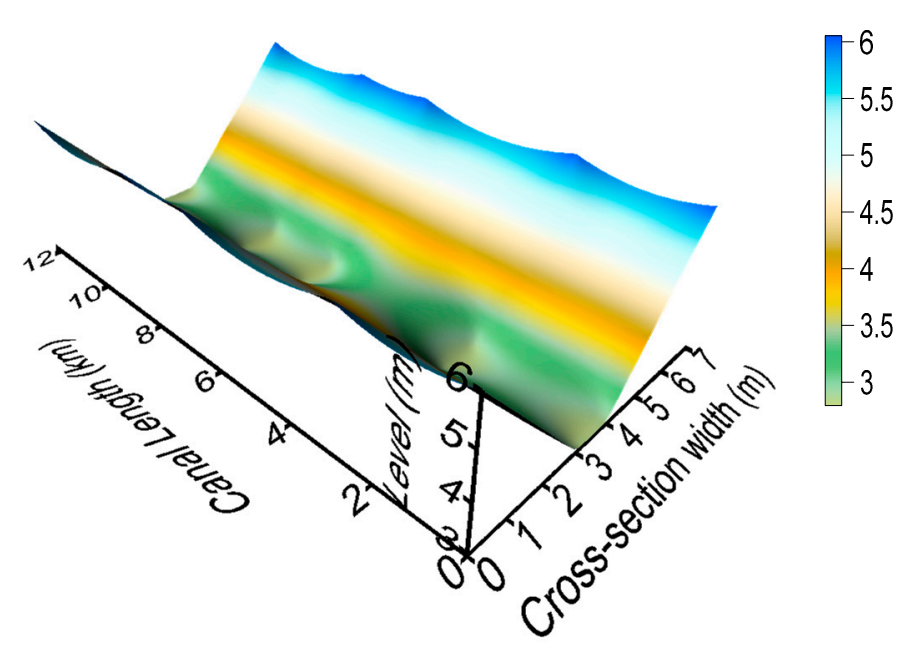

(c) 3D map for the designed cross-section

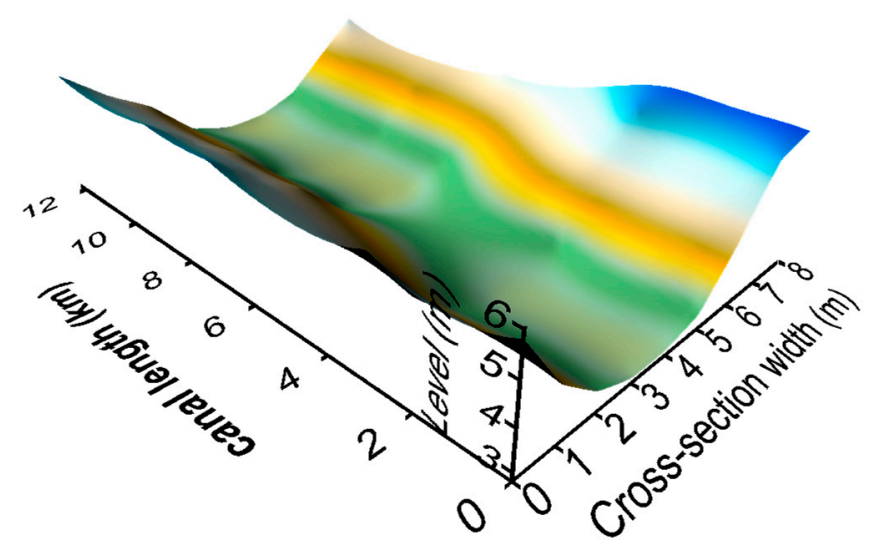

(d) 3D map for the current cross-section

Figure 5. Comparison between contour map and 3D map for original-designed and current cross-sections of Goifel canal. (a) Contour map of designed cross-section; (b) Contour map for the current cross-section; (c) 3D map for the designed cross-section; (d) 3D map for the current cross-section. 
These changes have taken place due to decades of dredging; the original-designed cross-section appears in red and is smaller than the operative (current) cross-section, which is shown in blue. The results indicate that considerable changes have occurred in Goifel canal morphology from the intake. (Figure $6 \mathrm{a}$ ) to the end along a reach of $12.25 \mathrm{~km}$ (Figure $6 \mathrm{~b}$ ), whereby the cross-section for the reach at $7.00 \mathrm{~km}$ is applicable until the end of the canal; the other cross-sections are estimated, and duplication is excluded. The paired figures documented expansion in cross-sections, making the canals deeper and wider, but in some cases, the widening appears clearly on one side, while the other side keeps its morphology, proving that the process of dredging was applied randomly. The morphology of the operated cross-sections showed a deformation to the ordinary trapezoidal cross-section of the canal and to attain the desired level of surface water supply, the canal demands more water than estimated. The displacement occurred in one of the canal sides decreased the width of the road by two meters, as shown in Figure 6.

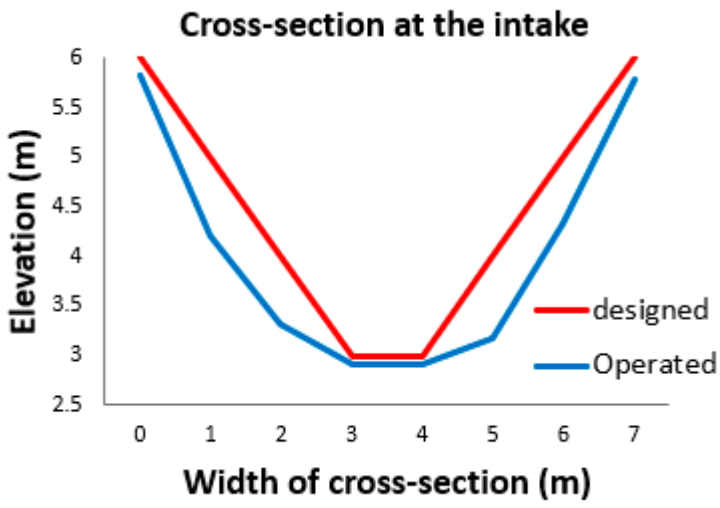

(a)

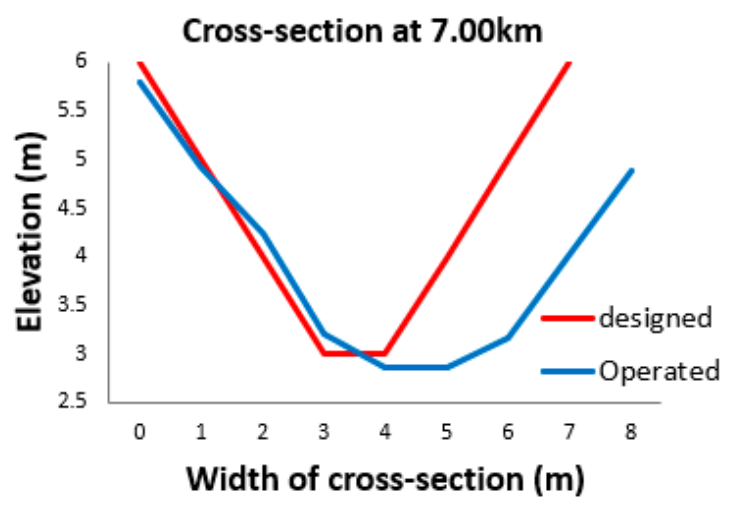

(b)

Figure 6. Changes in morphology of Goifel canal. (a) Cross-sections at intake; (b) Cross-sections at $7.0 \mathrm{~km}$ from intake.

Although the shapes in Figure 7 appear similar, they show differences in level and length of the section, as explained in Table 3, which includes data regarding the original and operative cross-sections for the canals considered in this study. Figure 7 shows the changes in Mashalaa canal morphology along different sections of its length, where all cross-sections become deeper and wider from both sides, as well as the bed. Figure $7 \mathrm{a}-\mathrm{g}$ are cross-sections at the inlet of the canal and then on reaches at $0.9 \mathrm{~km}, 1.5 \mathrm{~km}, 2.3 \mathrm{~km}, 2.9 \mathrm{~km}, 3.5 \mathrm{~km}$ and $4.1 \mathrm{~km}$, sequentially. The cross-section of $4.1 \mathrm{~km}$ was applied to the end of the canal. It was noticed that the growth in cross-sections increased when approaching the canal end, indicating that the same style of dredging was applied to all its sections, not taking into consideration that the bed width becomes narrower whenever approaching the end of a canal in the original cross-sections, where the served area decreased by going to the end. For this reason, the difference in morphology between the designed and operative cross-sections increases when progressing towards the end of a canal. In spite of the changes in the morphology, the random dredging did not affect the road width, while it still requires more amount of water than the estimated amount. Furthermore, it can be seen that the designed trapezoidal cross-section has been deformed. 


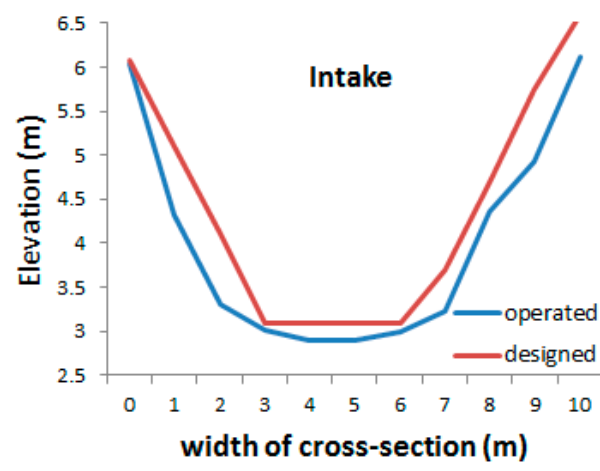

(a)

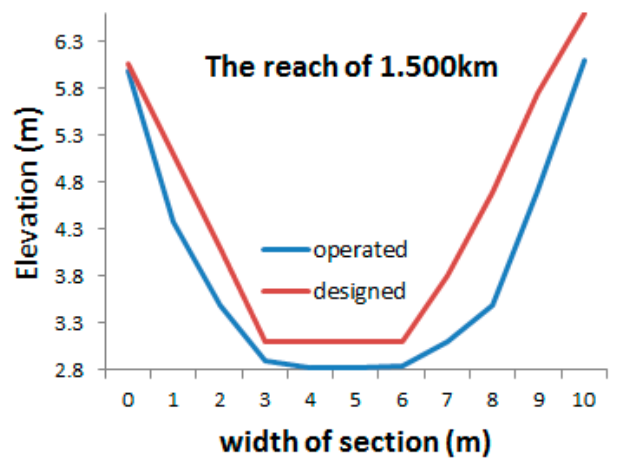

(c)

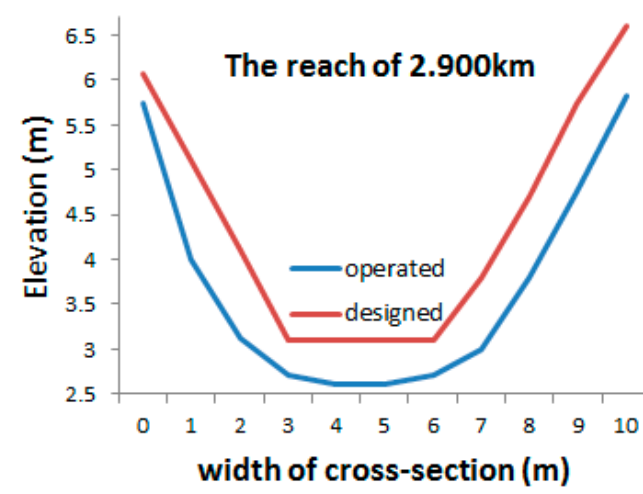

(e)

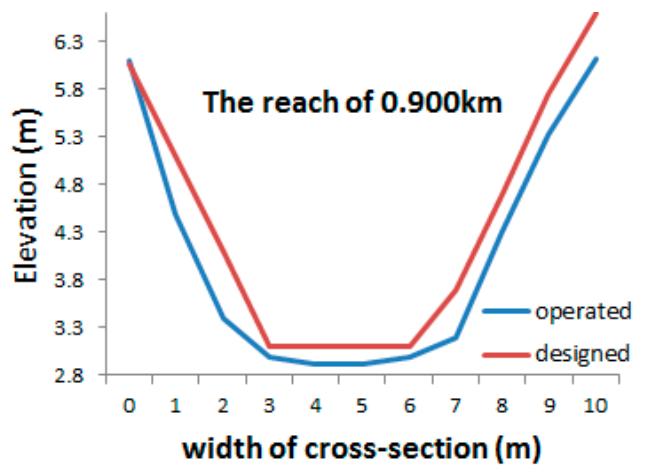

(b)

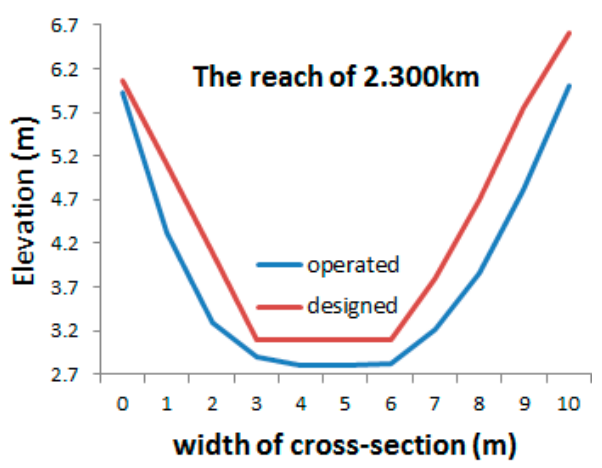

(d)

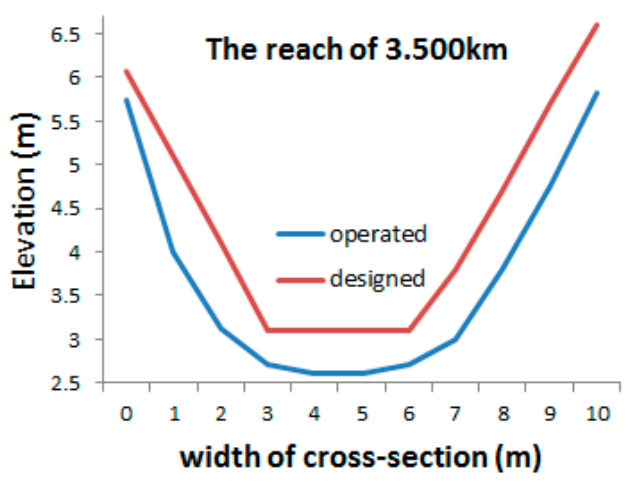

(f)

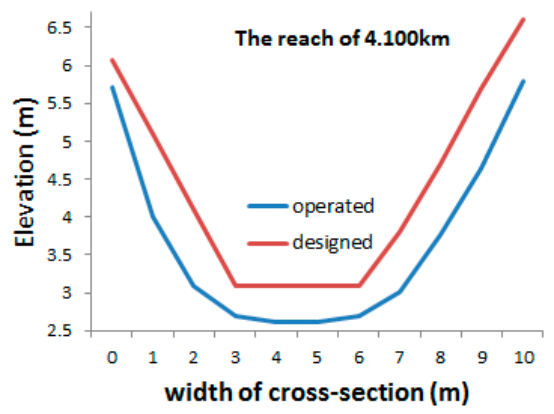

(g)

Figure 7. Changes in morphology along Mashalaa canal. (a) Cross-sections at intake; (b) Cross-sections at $0.9 \mathrm{~km}$ from intake; (c) Cross-sections at $1.5 \mathrm{~km}$ from intake; (d) Cross-sections at $2.3 \mathrm{~km}$ from intake; (e) Cross-sections at $2.9 \mathrm{~km}$ from intake; (f) Cross-sections at $3.5 \mathrm{~km}$ from intake; (g) Cross-sections at $4.1 \mathrm{~km}$ from intake. 
Figure 8 shows the variation in morphology of Rageb canal between the intake and the reach at $0.9 \mathrm{~km}$. This variation is due to cross-section expansion and involves both the bed, which has a lower level, as well as the sides, which become wider in both cross-sections, as seen in Figure 8a,b.

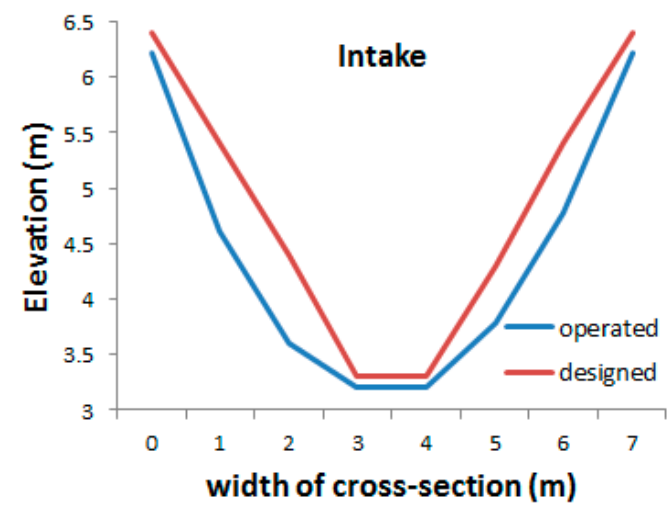

(a)

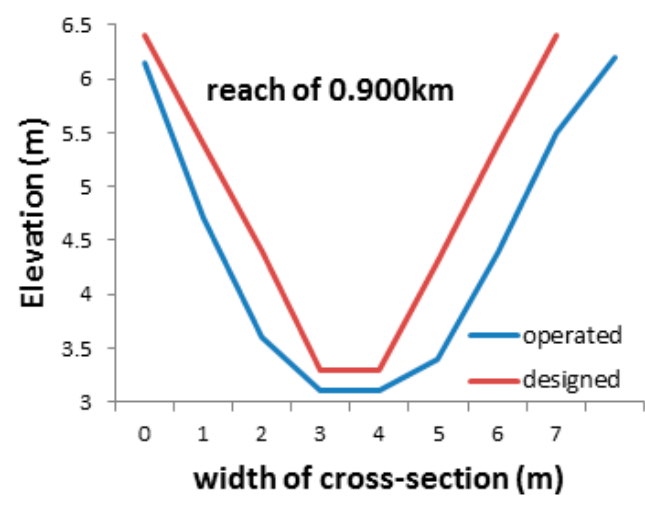

(b)

Figure 8. Changes in morphology of Rageb canal. (a) Cross-sections at intake; (b) Cross-sections at $0.9 \mathrm{~km}$ from intake.

Figure 9 shows the changes in the morphology of Mansher canal on different sections from its intake to the end, illustrating the expansion of the canal cross-sections along the studied sections, which become deeper and wider, although Figure $9 \mathrm{f}$ shows the section at $3.90 \mathrm{~km}$ with a tightened cross-section from one side, this time due to uneven dredging. The difference in morphology at the intake is an exception, where it was minor, as seen in Figure 9a. The worst case is shown in Figure 9c, which shows major expansion between the compared cross-sections of the canal. In Figure 9g, the majority of expansion was in the bed and one side.

Figure 10 shows the changes in morphology along Trandifilo canal, first at the intake, then on the reach at $1.50 \mathrm{~km}$, and the reach at $2.30 \mathrm{~km}$. Figure $10 \mathrm{a}-\mathrm{c}$ show that the operative cross-sections become deeper and wider than the original-designed cross-sections.

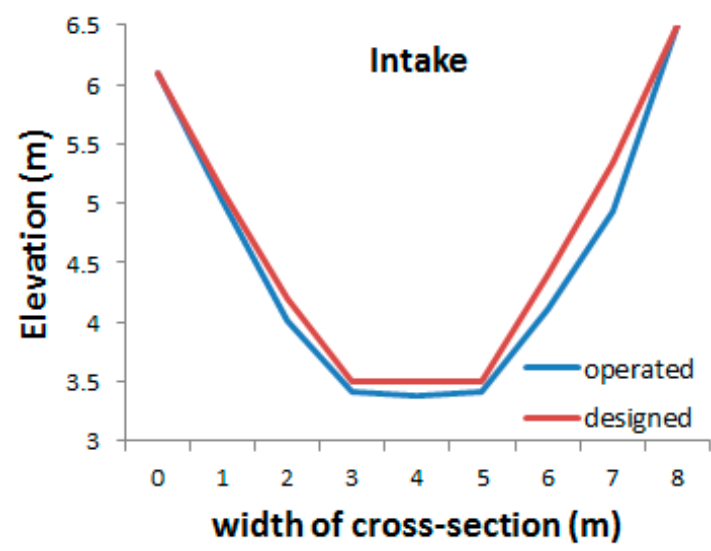

(a)

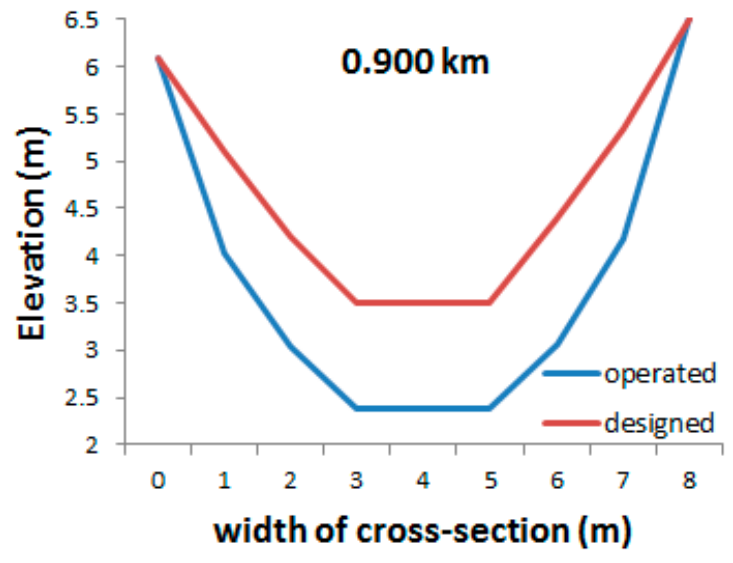

(b)

Figure 9. Cont. 


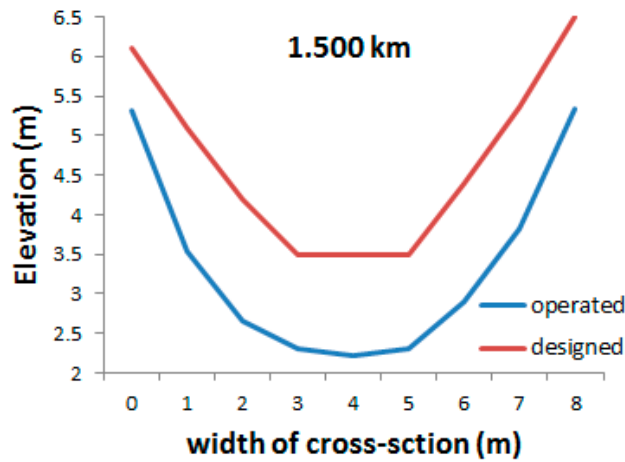

(c)

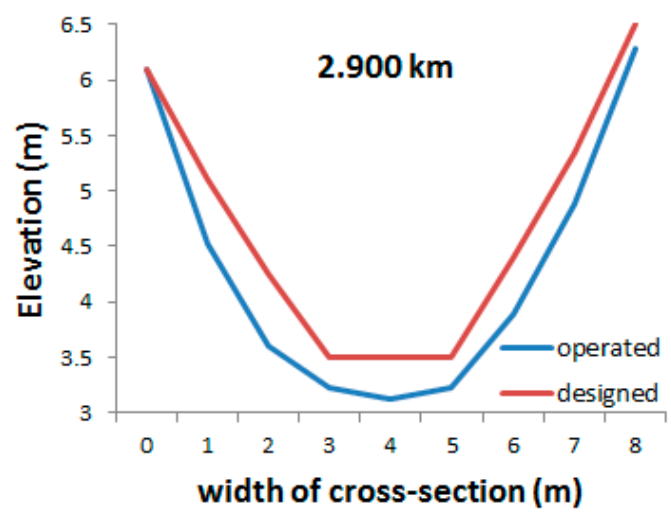

(e)

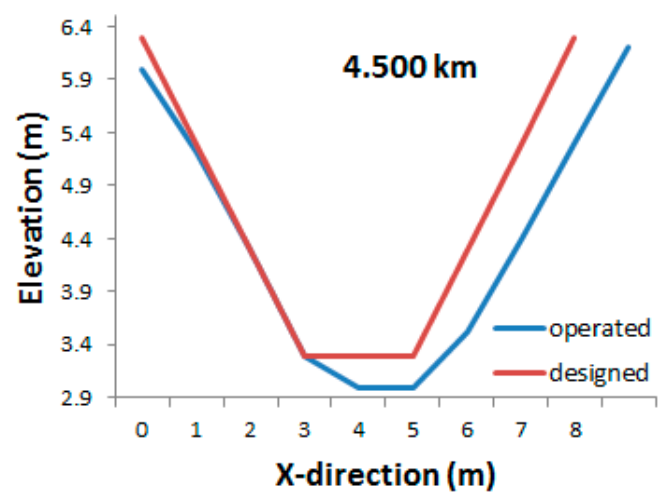

$(\mathrm{g})$

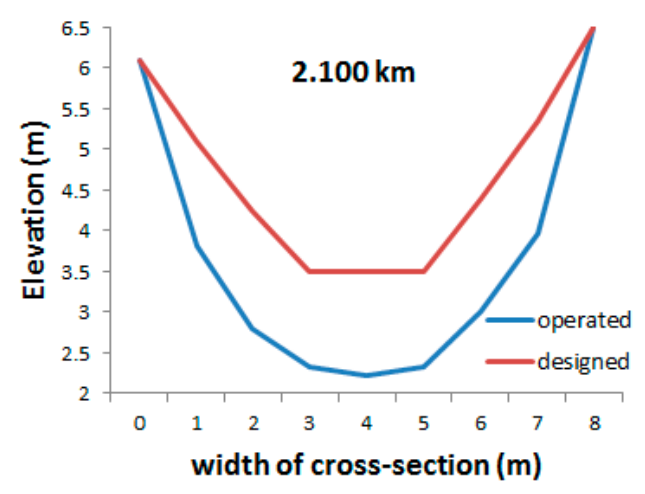

(d)

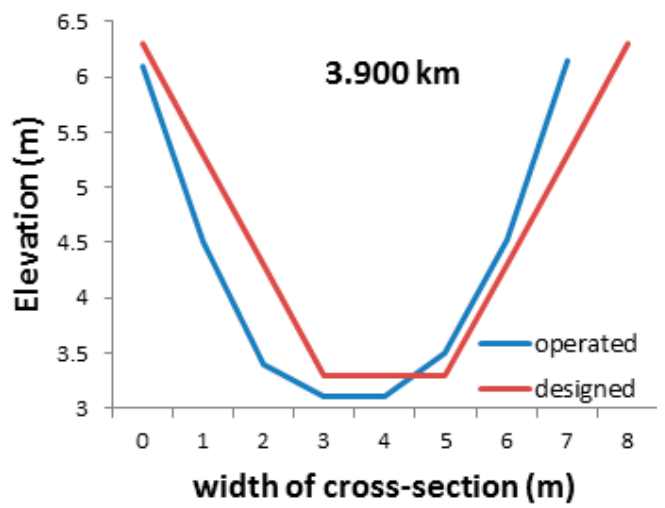

(f)

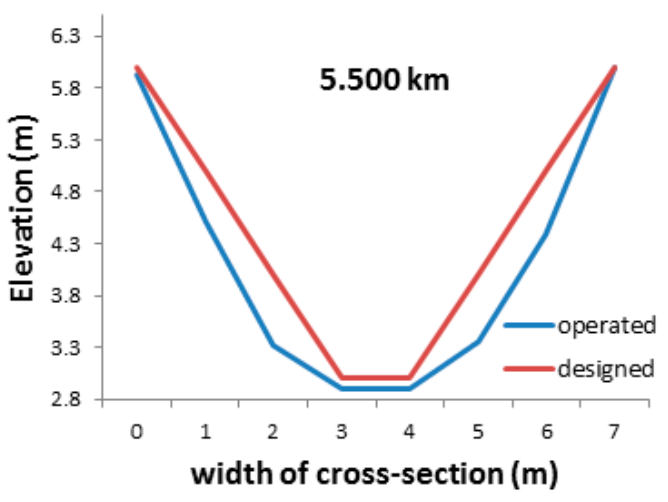

(h)

Figure 9. Changes in morphology of Mansher canal. (a) Cross-sections at intake; (b) Cross-sections at $0.9 \mathrm{~km}$ from intake; (c) Cross-sections at $1.5 \mathrm{~km}$ from intake; (d) Cross-sections at $2.1 \mathrm{~km}$ from intake; (e) Cross-sections at $2.9 \mathrm{~km}$ from intake; (f) Cross-sections at $3.9 \mathrm{~km}$ from intake; (g) Cross-sections at $4.5 \mathrm{~km}$ from intake; (h) Cross-sections at $5.5 \mathrm{~km}$ from intake.

\subsection{Effects of Dredging on Water Flow Rate}

Water flow rates for dredged and non-dredged canals, as well as net volume, which represents the difference between volumes of water in the two cases, were determined using Surfer. Table 4 presents the results of the simulation for the amount of water in dredged canals. It includes the water volumes in original sections and operative canals, and the percentage of increase in water volume, the estimated actual discharge, excess volume of water/day and the excess volume of water/year for each canal. The actual discharge in the canals is estimated monthly by MWRI and represents the real discharge in 
the canal, whereas the supply of water in Egypt is related to desired levels. The flow in the canals is measured through rectangle-notch weirs. The results indicate an increase in water requirement after dredging, although the increase looks minor in the case of the Goifel canal, but even there, the estimated excess volume per day approaches 0.1832 million $\mathrm{m}^{3}$, which is sufficient for 60,560 people with an average daily consumption of $300 \mathrm{~L} /$ day. The other four canals greatly exceeded the Goifel canal in their excess water due to dredging. The results also show that the excess amount of water after dredging is not a function of canal length, because it is related to the manner of dredging application.

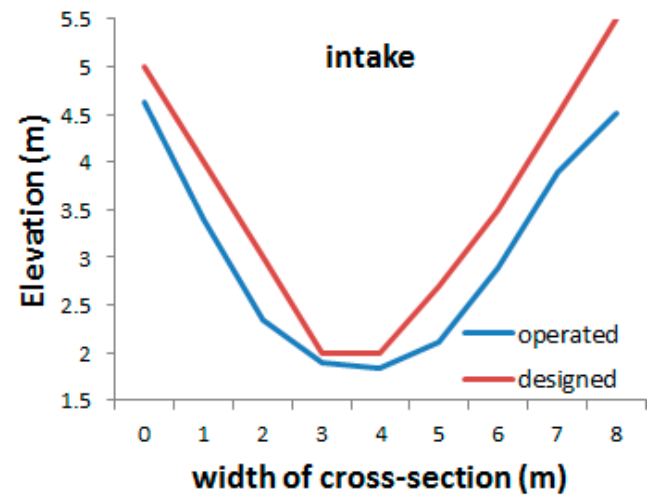

(a)

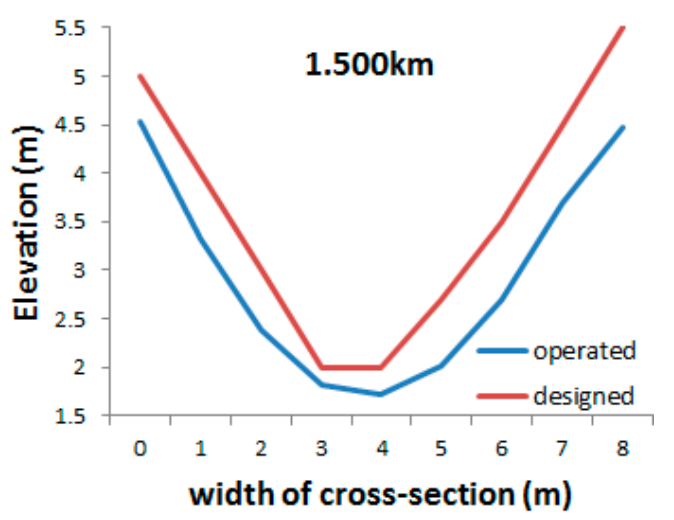

(b)

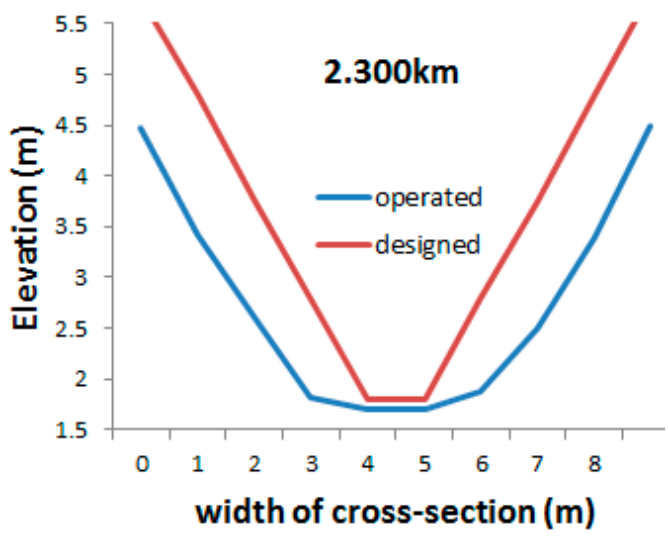

(c)

Figure 10. Changes in morphology of Trandifilo canal. (a) Cross-sections at intake; (b) Cross-sections at $1.5 \mathrm{~km}$ from intake; (c) Cross-sections at $2.3 \mathrm{~km}$ from intake.

Table 4. Variations in the quantity of water in the five canals.

\begin{tabular}{cccccc}
\hline Canal & Goifel & Mansher & Mashalaa & Rageb & Trandifilo \\
\hline Designated volume $\left(\mathrm{m}^{3}\right)$ & 1277 & 7857 & 6909 & 1202 & 2455 \\
Current volume $\left(\mathrm{m}^{3}\right)$ & 1303 & 10,467 & 10,677 & 1569 & 3896 \\
increase in water volume $\%$ & $2 \%$ & $33 \%$ & $55 \%$ & $31 \%$ & $59 \%$ \\
Q actual $\left(\mathrm{m}^{3} / \mathrm{s}\right)$ & 2.12 & 2.64 & 2.88 & 2.09 & 1.97 \\
Excess vol./day $\left(\mathrm{m}^{3}\right)$ & 183,168 & 228,096 & 248,832 & 180,576 & 170,208 \\
Excess vol./year $\left(\mathrm{mill}^{3} \mathrm{~m}\right)$ & 66.9 & 83.26 & 90.82 & 65.91 & 62.13 \\
\hline
\end{tabular}

Figure 11 shows the relation between the volume of sediment removed from the bed of the examined canals. The horizontal axis represents the length of canals, while the vertical axis represents the removed volume for each canal. In most cases, the relation between the canal length and the 
removed volume was strong, except in the case of Goifel canal, with a correlation factor of more than 0.90. The relation can be expressed as a linear function, as shown in Equation (2).

$$
\mathrm{Y}=938.6 \mathrm{X}-1173.4
$$

where:

Y: amounts of sediment removed from canal beds $\left(\mathrm{m}^{3}\right)$

$\mathrm{X}$ : length of canal $(\mathrm{km})$

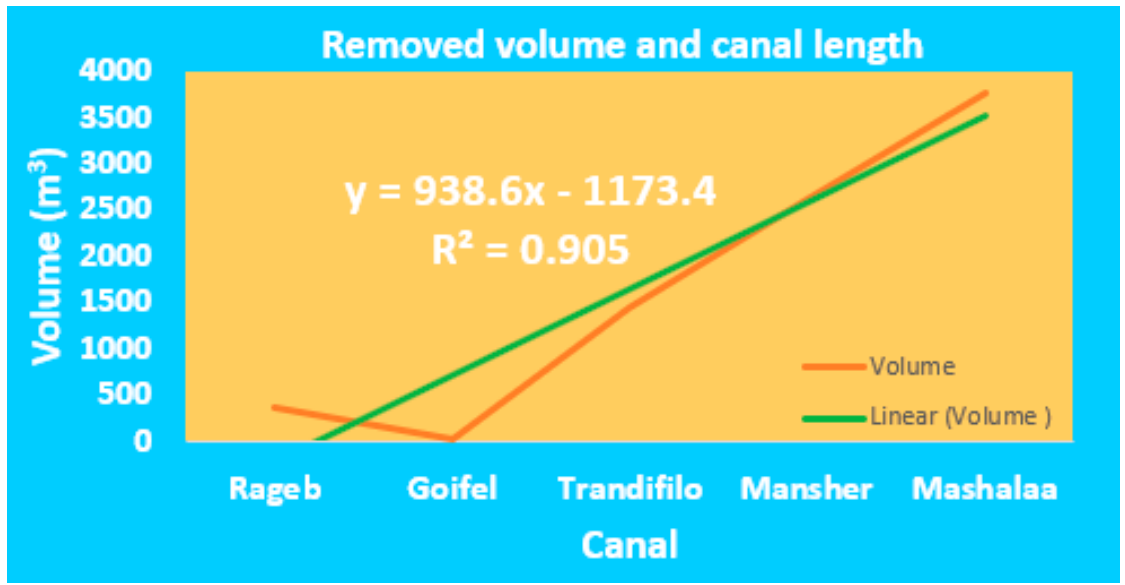

Figure 11. Relation between removed sediment volume and canal length.

Rehabilitation of irrigation canals (RIC) is a new urgent policy adopted by MWRI within the framework of wise management of surface water due to water crisis in Egypt. RIC aims to restore the original-designed cross-sections of canals in the irrigation network. Surface water delivery through designed cross-sections will save amounts of water equivalent to the removed parts of canal beds through maintenance by dredging. The total length of the selected canals is $21.475 \mathrm{~km}$, so the amount of water saved is expected to reach 0.02 million $\mathrm{m}^{3}$ according to Equation (2), and additionally there will be an amount of water saved of about 0.21 million $\mathrm{m}^{3}$ for the total length of the irrigation canals in the pilot area, as seen in Table 5. RIC is targeted to reach a length of $1500 \mathrm{~km}$ by June $2020,3000 \mathrm{~km}$ by December 2020, and $7000 \mathrm{~km}$ by the year 2022. Through this scheme, Egypt will save amounts of water reaching 1.41 million $\mathrm{m}^{3}$, 2.81 million $\mathrm{m}^{3}$ and 6.56 million $\mathrm{m}^{3}$, respectively. Bashir et al. [32] discussed the natural ability of water to neutralize pollution, while the uncontrolled pollution removed this property from water; hence, regular monitoring and controlling of pollutant discharge into surface water is a must. Therefore, the RIC may be ineffective if companies conduct the same anthropogenic activities, so urgent procedures should be applied to sustain the cleanliness of the canals as much as possible. Some of the most urgent procedures are awareness programs to reach awareness among residents to be careful and knowledgeable of the temporal and spatial importance of ensuring canals remain clean, potential consequences on surface water quality and quantity, and the reversion of health and water requirements. Enactment and activation of deterrent laws, in parallel with the awareness programs, are essential for managing waterways.

Table 5. Variations in quantity of water in the five canals.

\begin{tabular}{cccccc}
\hline & $\begin{array}{c}\text { Case } \\
\text { Study }\end{array}$ & $\begin{array}{c}\text { Pilot } \\
\text { Area }\end{array}$ & $\begin{array}{c}\text { Egypt June } \\
\mathbf{2 0 2 0}\end{array}$ & $\begin{array}{c}\text { Egypt } \\
\text { December 2020 }\end{array}$ & $\begin{array}{c}\text { Egypt } \\
\mathbf{2 0 2 2}\end{array}$ \\
\hline $\begin{array}{c}\text { Length of rehabilitated } \\
\text { canals (km) }\end{array}$ & 21.475 & 223.855 & 1500 & 3000 & 7000 \\
\hline Saved water (million $\mathbf{~ m}^{\mathbf{3}}$ ) & 0.019 & 0.209 & 1.407 & 2.815 & 6.569 \\
\hline
\end{tabular}




\section{Discussion}

Utilization of irrigation canals for purposes other than providing water changed the morphology of the canals beside degraded the quality of surface water. Getting rid of solid pollutants in waterways deforms canals cross-sections, due to the accumulation of the pollutant's layers by time. Thus, this turned the designed cross-sections of canals into the narrower case. The continued dredging of canals is not a suitable solution to restore the original cross-sections, where such a type of implementation enlarged the cross-sections. Since providing water in Egypt was linked with reference levels, additional amounts of surface water were supplied, where the area of some canals increased by more than half, as seen in Mashalaa and Trandifilo canals. There was a marked relation between the canal's length and the removed volume of its boundaries, with a correlation factor exceeding 0.90 .

The obtained relation, expressed as a linear function, was used to predict the amounts of surface water saving in the future. Initially, it estimated the saved water for the selected canals, the pilot area and the irrigation network of Egypt by June 2020, by December 2020 and by 2022, respectively. The RIC could rectify the discussed difficulty by returning the designed cross-sections of canals and saved amounts of water reached to 6.57 million $\mathrm{m}^{3}$ by the year 2022. Canals which not Subject to the RIC should have a suggested plan for dredging before the implementation, depending on simulation models, such as ElGamal and ElGazzar [33], who targeted the modification of the hydraulic capacity of El-Bagoriya canal, Middle Delta of Egypt, to improve water supply to the downstream through a plan to dredge the canal. Surveying of cross-sections and creating contours maps were performed for this purpose. The simulation model checked original cross-sections, the suggested dredging scenario and the actual dredging. The results proved that the suggested dredging could improve the flow, as opposed to the actual dredging. Crişu et al. [34] investigated the current state of $1.015 \mathrm{~km}$ canals and the morphological changes in Romania; this enabled the estimation of the removed volumes, which reached 53.918 million $\mathrm{m}^{3}$. The RIC targeted to restore the initial cross-sections by 2020 , to increase the cultivated areas.

\section{Conclusions}

The consequences of anthropogenic activity and improper dredging affect the morphology of canals; the former makes them narrow, and the latter makes them wider, so the canals do not retain a constant shape. The impacts of anthropogenic activity on canal morphology and capacity are assessed in the current study, comparing the operative to the originally designed cross-sections. This study is applied to five canals in the Nile Delta, Egypt. The selected canals demonstrate the problem of invasive maintenance, just like the other canals in the Egyptian Delta. These canals are extremely affected by anthropogenic activity, as well as dredging by the government. Random dredging can lead to permanent changes in canal morphology, which in turn could affect the canals' function of supplying water. The study assesses the increase in water volume by comparing each canal's designated cross-section and operative cross-section, which is termed as "net volume".

The designed cross-sections describe the canals' morphology before operation, while the current cross-sections reveal the dimensions of canals after the double action of anthropogenic activity and maintenance. The study compares the morphology of the originally designed cross-sections to the final morphology of the canal cross-sections due to operation and dredging, and their effect on water volume in the canals. Surfer software was used to determine the net volume of canals before and after dredging. The results showed grave changes in the morphology of the studied canals' cross-sections. The examined cross-sections acquire more area as they become wider and deeper, which negatively affects the functioning of the canals. The five studied canals showed enlargement in cross-sections due to the annual uncharted dredging process. The percentage increase in the volume of water in the canals was extremely high in some cases, such as in Mashalaa and Mansher canals, which have the greatest length among the five canals, while population growth absorbs the excess amount of water in the larger sections.

Clear changes in canal morphology were observed in all studied canals, considerably enlarging the cross-section areas of the canals. The results reveal that increasing the cross-section area through 
dredging requires more water to reach the same level in the canals required for irrigation, drinking and industry. The increases in water volume were found to be $2 \%, 33 \%, 55 \%, 31 \%$ and $59 \%$ for the Goifel, Mansher, Mashalaa, Rageb and Trandifilo canals, respectively, exacerbating the problem of surface water shortages. For sustainable management of water resources in Egypt, the current governmental policies limit maintenance by dredging only to hot sections and apply national plan for canal rehabilitation, which could help to meet the set objectives in saving water by the year 2022 . The amount of water saved is about 6.56 million $\mathrm{m}^{3}$, this value is predicted through an induced linear function and represents a strong relation between the saved amount of water and the canal lengths, with a correlation factor $\mathrm{R}^{2}$ of more than 0.90 .

Author Contributions: Conceptualization, H.F.A.-E. and S.A.-E.; data curation, P.P.; formal analysis, P.M.; funding acquisition, P.M.; investigation, S.A.-E.; methodology, S.A.-E.; project administration, M.Z.; resources, P.M.; software, P.P.; supervision, M.Z. and H.F.A.-E.; validation, H.F.A.-E.; visualization, P.P.; writing-original draft preparation, S.A.-E.; writing-review and editing, M.Z. All authors have read and agreed to the published version of the manuscript.

Funding: This research received no external funding.

Acknowledgments: Thank you for the support of project KEGA 059TUKE-4/2019 M-learning tool for intelligent modeling of building site parameters in a mixed reality environment. This work was supported by the Slovak Research and Development Agency under the contract no. APVV-17-0549 Research of knowledge and virtual technologies supporting intelligent design and implementation of buildings with emphasis on their economic efficiency and sustainability.

Conflicts of Interest: The authors declare no conflict of interest.

\section{References}

1. Khatri, N.; Tyagi, S. Influences of natural and anthropogenic factors on surface and groundwater quality in rural and urban areas. Front. Life Sci. 2015, 8, 23-39. [CrossRef]

2. Singh, R.; Kanbienaa, D.; Pandey, A. Water Quality Status of Upper Ganga Canal. In Climate Impacts on Water Resources in India; Springer: Berlin/Heidelberg, Germany, 2020; pp. 21-34.

3. Egessa, R.; Nankabirwa, A.; Ocaya, H.; Pabire, W.G. Microplastic pollution in surface water of Lake Victoria. Sci. Total Environ. 2020, 741, 140201. [CrossRef]

4. Khalidullin, O. Water, Electric Energy and Flood. OAGESS 2019, 2, 209-210. [CrossRef]

5. Soti, P.; Goolsby, J.A.; Racelis, A. Agricultural and Environmental Weeds of South Texas and their Management. Subtrop. Agric. Environ. 2020, 71, 1-11.

6. El Ella, S.; El Samman, T. Review: Egyptian Experience in Controlling Aquatic Weeds. J. Am. Sci. $2016,12$. [CrossRef]

7. Bray, N.; Cohen, M. Dredging for Development; International Association of Dredging Companies (IADC): Leidschendam-Voorburg, The Netherlands; International Association of Ports and Harbours (IAPH): Tokyo, Japan, 2010.

8. Shademani, S.; Zarafshan, P.; Khashehchi, M.; Kianmehr, M.; Hashemy, S. Conceptual design and analysis of a dredger robot for irrigation canals. Ind. Robot Int. J. Robot. Res. Appl. 2019, 46, 819-827. [CrossRef]

9. Maheshvaran, V.; Murali, K.; Sundar, V.; Chitra, K. Study on Maintenance Dredging for Navigable Depth Assurance in the Macro-tidal Hooghly Estuary. In Proceedings of the Fourth International Conference in Ocean Engineering (ICOE2018), Glasgow, UK, 2-4 October 2018; pp. 353-367.

10. Destefani, A.; Resgalla, C., Jr. Integrated evaluation of accumulated sediments in a buried channel of a subtropical estuary. Reg. Stud. Mar. Sci. 2019, 25, 100453. [CrossRef]

11. Pillo, R.; Girolamo, A.; Todisco, M. Modelling the silting-up of a small reservoir fed by a temporary river: The Torrebianca reservoir study case (Puglia, SE Italy). J. Mater. Environ. Sci. 2019, 10, 225-233.

12. Zhang, L.; Yuan, B.; Yin, X.; Zhao, Y. The Influence of Channel Morphological Changes on Environmental Flow Requirements in Urban Rivers. Water 2019, 11, 1800. [CrossRef]

13. Yang, L.; Liu, F.; Gong, W.; Cai, H.; Yu, F.; Pan, H. Morphological response of Lingding Bay in the Pearl River Estuary to human intervention in recent decades. Ocean Coast. Manag. 2019, 176, 1-10. [CrossRef]

14. Kamal, N.; Sadek, N. Evaluating and analyzing navigation efficiency for the River Nile (Case study: Ensa-Naga Hamady reach). Ain Shams Eng. J. 2018, 9, 2649-2669. [CrossRef] 
15. Dépret, T.; Piégay, H.; Dugué, V.; Vaudor, L.; Faure, J.-B.; Le Coz, J.; Camenen, B. Estimating and restoring bedload transport through a run-of-river reservoir. Sci. Total Environ. 2019, 654, 1146-1157. [CrossRef]

16. Junakova, N.; Junak, J. Alternative reuse of bottom sediments in construction materials: Overview. In IOP Conference Series: Materials Science and Engineering; IOP Publishing: Bristol, UK, 2019; p. 012038.

17. De Vincenzo, A.; Covelli, C.; Molino, A.J.; Pannone, M.; Ciccaglione, M.; Molino, B. Long-term management policies of reservoirs: Possible re-use of dredged sediments for coastal nourishment. Water 2019, 11, 15. [CrossRef]

18. Sobeih, M.M.; Sadek, N.E.-S.; Helal, E.E.-D.Y.; Mohamed, N. Evaluating Efficiency of the river nile navigational path. IWTJ 2017, 7, 209-222.

19. Mossa, J.; Chen, Y.-H.; Walls, S.P.; Kondolf, G.M.; Wu, C.-Y. Anthropogenic landforms and sediments from dredging and disposing sand along the Apalachicola River and its floodplain. Geomorphology 2017, 294, 119-134. [CrossRef]

20. Kuriqi, A.; Koçileri, G.; Ardiçlioğlu, M. Potential of Meyer-Peter and Müller approach for estimation of bed-load sediment transport under different hydraulic regimes. Modeling Earth Syst. Environ. 2020, 6, 129-137. [CrossRef]

21. Abdelhaleem, F.S.; Amin, A.M.; Basiouny, M.E.; Ibraheem, H.F. Adaption of a formula for simulating bedload transport in the Nile River, Egypt. J. Soils Sediments 2020, 20, 1742-1753. [CrossRef]

22. Fathy, H.; Amin, A.M.; Abdelhaleem, F.S.; Basiouny, M.E. Experimental Approach for Bed Load Transport of Non-Uniform Sediment of the Nile River, Egypt. CERM 2020, 42, 195-213.

23. Coulthard, T.J.; Van De Wiel, M.J. Modelling long term basin scale sediment connectivity, driven by spatial land use changes. Geomorphology 2017, 277, 265-281. [CrossRef]

24. Pasculli, A.; Audisio, C. Cellular automata modelling of fluvial evolution: Real and parametric numerical results comparison along River Pellice (NW Italy). Environ. Modeling Assess. 2015, 20, 425-441. [CrossRef]

25. Ramachandra, T.; Vinay, S.; Bharath, S.; Chandran, M.; Aithal, B.H. Insights into riverscape dynamics with the hydrological, ecological and social dimensions for water sustenance. Curr. Sci. (00113891) 2020, 118, 1379-1393.

26. Kuriqi, A.; Pinheiro, A.N.; Sordo-Ward, A.; Garrote, L. Water-energy-ecosystem nexus: Balancing competing interests at a run-of-river hydropower plant coupling a hydrologic-ecohydraulic approach. Energy Convers. Manag. 2020, 223, 113267. [CrossRef]

27. El Kafrawy, S.B.; Ahmed, M.H. Monitoring and Protection of Egyptian Northern Lakes Using Remote Sensing Technology. In Environmental Remote Sensing in Egypt; Springer: Berlin/Heidelberg, Germany, 2020; pp. 231-284.

28. Dutta, V.; Sharma, U.; Kumar, R. Restoring Environmental Flows for Managing River Ecosystems: Global Scenario with Special Reference to India. In Environmental Concerns and Sustainable Development; Springer: Berlin/Heidelberg, Germany, 2020; pp. 163-183.

29. MWRI. Available online: https://geoportal.mwri.gov.eg/portal/home/ (accessed on 14 November 2020).

30. Abd-Elaziz, S.; Zeleňáková, M.; Mésároš, P.; Purcz, P.; Abd-Elhamid, H. Assessing the Potential Impacts of the Grand Ethiopian Renaissance Dam on Water Resources and Soil Salinity in the Nile Delta, Egypt. Sustainability 2019, 11, 7050.

31. Bresnahan, T.; Dickenson, K. Surfer 8 Self-Paced Training Guide; Golden Software Inc.: Golden, CO, USA, 2002.

32. Bashir, I.; Lone, F.; Bhat, R.A.; Mir, S.A.; Dar, Z.A.; Dar, S.A. Concerns and Threats of Contamination on Aquatic Ecosystems. In Bioremediation and Biotechnology; Springer: Berlin/Heidelberg, Germany, 2020; pp. 1-26.

33. ElGamal, T.; ElGazzar, M. Applying Modern Surveying Techniques and Simulation Models for The Rehabilitation of Main Canals in Egypt: Case Study-El-Bagoriya Canal. J. Soil Sci. Agric. Eng. 2020, 11, 445-454.

34. Crişu, L.; Zamfir, A.G.; Boengiu, S. Morphological changes induced by the irrigation systems and sustainable land use in baileşti plain. Present Environ. Sustain. Dev. 2020, 14, 293-309. [CrossRef]

Publisher's Note: MDPI stays neutral with regard to jurisdictional claims in published maps and institutional affiliations.

(C) 2020 by the authors. Licensee MDPI, Basel, Switzerland. This article is an open access article distributed under the terms and conditions of the Creative Commons Attribution (CC BY) license (http://creativecommons.org/licenses/by/4.0/). 